\title{
PRECISIONES SOBRE LA EXPANSIÓN MARÍTIMA DE LA CORONA DE ARAGÓN
}

\author{
Álvaro Santamaría
}

\section{EL TEMA}

1. La expansión marítima de la Corona de Aragón tema relevante, complejo y polémico.

Tema relevante por su ejecutoria como una de las dimensiones hispánicas cardinales en el marco mediterráneo bajo medieval, entendido como área marítima de choque de múltiples y contrapuestos intereses que relacionan y enfrentan en intrincado laberinto a la Unión de la Corona de Aragón con la Monarquía francesa y sus aliados, con el Pontificado, con las potencias mercantiles italianas -Pisa, Génova y Venecia-, con las tensiones entre güelfos y gibelinos, con el imperio de Oriente y, por supuesto, con la Corona de Castilla y con el mundo islámico peninsular y mediterráneo.

Tema complejo por su amplitud temporal, por lo menos del siglo XIII al siglo XVI, y sobre todo por la diversidad de sus componentes económicos, políticos, ideológicos y sociológicos. $Y$ tema polémico porque al implicar intereses de tantos entes políticos y al inferirse tan diversos componentes como los relacionados que propician análisis desde ópticas subjetivas, la objetivación y clarificación historiográfica del tema resulta en ocasiones problemática.

2. El tema ha suscitado numerosas aportaciones bibliográficas y algunos estudios globales como el del profesor Jesús Lalinde Abadía sobre la 
Corona de Aragón en el Mediterráneo Medieval (1). Las posturas subjetivas se manifiestan en especial en "la historiografía española en la que, como ha señalado cabalmente el profesor Lalinde, la historiografía catalana tiende a considerar la expansión mediterránea de la Corona de Aragón como una empresa gloriosa que corresponde casi en exclusiva a los catalanes, de los que -según interpretan- los valencianos y mallorquines sólo son parte, y minimiza la aportación aragonesa que, tímidamente, es defendida por los historiadores de este origen. Los castellanos y españoles no catalanes, incluidos los aragoneses, o se muestran fríos si la consideran empresa catalana o la exaltan si la consideran española o, en todo caso, aragonesa" (2).

Los estudios realizados ofrecen un panorama de las diversas etapas del desarrollo temporal de la expansión mediterránea de la Corona de Aragón concertados preferentemente en la vertiente política sobre la que obran suficientes fuentes como para esclarecerla con cierta puntualidad. Otras vertientes sustanciales del tema como la etiología, su dinámica y las secuelas socioeconómicas de la expansión presentan sombras y lagunas que demandan indagaciones laboriosas y sosegadas para verificar, al amparo de fuentes adecuadas, algunas de las conjeturas formuladas; a veces conjeturas brillantes que, de momento, sólo pueden asumirse como ingeniosas hipótesis de trabajo.

El presente estudio intenta establecer una aproximación global, a ser posible clarificadora, centrada sólo sobre los tres siguientes aspectos más polémicos de la problemática:

- Esquema cronológico de la expansión.

- Etiología e interpretación de la expansión.

- Financiación de la expansión.

\section{SOBRE EL ESQUEMA CRONOLÓGICO DE LA EXPANSIÓN}

\section{Los hitos cronológicos habituales}

3. Esquema cronológico de la expansión no respecto a las etapas de desarrollo cronológico de la misma, suficientemente constatados, sino en relación a las balizas de la expansión, es decir, a la interpretación de los hitos cronológicos de arranque y de culminación de la expansión mediterránea. 
J. Lee Shneidman enmarca su estudio sobre el Imperio catalano-aragonés entre 1200 y 1350. ¿Por qué? Porque entiende que es durante dicho periodo cuando Cataluña -motor del imperio- adquiere conciencia de su identidad nacional, de su catalanidad diferencial. "Quant Jaume I enceta el cami -explica Shneidman- els catalans no sabien encara si eren francs o ibèrics. En temps de Pere III els catalans sabien que no eren cap de les dues coses. La batalla de Muret i el tractat de Corbeil els havien bandejat de les terres franceses; el diferent desemvolupament cultural i econòmic d'Aragó i de Catalunya inpedi que els catalans s'identifiquessin amb Aragó i la resta de la Peninsula: el resultat fou el convenciment de que eren únics. Els catalans s'identificaren amb Catalunya i el Casal de Barcelona. Entre 1346 i el 1348 moriren de bon grat per aquesta identificació".

Shneidman interpreta que Cataluña alcanza su madurez cuando $\mathrm{Pe}$ dro el Ceremonioso aplasta a los unionistas de Aragón y de Valencia. Refiere cómo "els ultres d'Aragó i de València restaren confusos" cómo "Bernat de Cabrera jugà destrament la carta de la qüestió econòmica per alçar un exercit capaç de derrotar als ultres", cómo "el virtual extermini dels ultres no significava que Pere tingués les mans lliures per reorganitzar la constitució aragonesa", y cómo tras la triunfal entrada del Ceremonioso en Valencia, vencidos los unionistas, "la justícia reial fou molt suau: els cabdills de la Unió foren decapitats, penjats o assasinats però els ciutadans no foren castigats" (3). Es interpretación respetable pero cuestionable.

El proceso histórico de maduración de la personalidad de Cataluña es, por supuesto, uno de los componentes principales de la expansión pero no puede ser asumido como eje de toda la problemática de la expansión cuya fenomenología es más relevante y más amplia. El estudio de Shneidman titulado en el original inglés The Rise of the Aragonese-Catalan Empire y que en la versión catalana se titula L'Imperi Catalano-Aragonès merece titularse por su orientación y contenido L'Imperi Català sin más.

Otros criterios historiográficos consideran con mejor sentido que la expansión iniciada con la conquista de Mallorca en 1229 prosigue por lo menos hasta 1479, data del acceso de Fernando el Católico. Estas balizas - de 1229 a 1479- son las más generalizadas, si bien cierta historiografía, de la que es símbolo Ferran Soldevila, entiende que la expansión se desnaturaliza a partir de 1412 al asentarse la Dinastía de Trastámara en la Corona de Aragón (4). Pienso que esas balizas -1229 y 1479- requieren ciertas matizaciones. 
4. "Amb la conquesta de Mallorca -afirma Ferran Soldevila- Catalunya no ha conseguit solament un tros del seu territori, ha iniciat tambe la seva expansió mediterrània. Mallorca és la primera anexió d'una cadena de terres insulars i peninsulars que seguira amb Eivissa, Sicília, Malta, Gozzo, Gerba, Menorca, Sardenya, Atenes, Neopàtria, Nàpols, Castellorizzo..."

Vicente Salavert sostiene -aunque refiriéndose a la Corona de Aragón y no a Cataluña en exclusiva- un criterio similar. "Los comienzos de la verdadera expansión mediterránea como fenómeno histórico sólo pueden fijarse -manifiesta Salavert- en el momento en que aparece una auténtica política de expansión, es decir, una idea reflexiva y metódica destinada a convertir -el Mediterráneo- poco a poco en un lago propio, lo que a nuestro entender únicamente tiene lugar con Jaime I.... Con la conquista de Mallorca, Cataluña -concluye Salavert- ha iniciado su expansión mediterránea".

La interpretación de Salavert que aparenta tan resolutiva como la de Ferran Soldevila, no obstante, es vacilante y ambivalente; pues, si bien subraya el contraste entre la conquista de Mallorca, apreciada como jalón de la expansión marítima mediterránea, y la conquista de Valencia, definida como reconquista peninsular, matiza de inmediato respecto a Mallorca que "quizá conviniera fijarse también en su vertiente de reconquista", y apunta la posibilidad de "fuera más empresa de reconquista, de limpieza de nidos de piratas, que mediterránea de expansión", y, respecto a Valencia precisa que su conquista también pudiera valorarse "bajo el aspecto de expansión marítima".

La postura algún tanto dubitativa de Salavert es comprensible; sin embargo, cuando una empresa presenta connotaciones plurales procede identificarla por sus connotaciones predominantes y en los supuestos del reino de Mallorca y del reino de Valencia las connotaciones etiológicas de "reconquista" predominan paladinamente sobre la connotaciones de "expansión mediterránea".

En todo caso la historiografía mayoritariamente, tanto la española como la extranjera, suele asumir sin razonarlo el criterio historiográfico de un proceso expansivo marítimo que se abre con Jaime I y se cierra con Alfonso el Magnánimo. Es el criterio que ha sintetizado con claridad Ciro Conca: "L'espansione della Corona d'Aragona nel Mediterraneo occidentale si apre, concretamente, con la conquista delle Baleari, a un terzo del secolo XIII; prosegue con la conquista della Sicilia e della Sardegna, tra la fine dell 
stesso secolo XIII e l'inicio del XIV, si conclude con la conquista del regno di Napoli, alla metà del secolo XV" (5).

2. El operativo Baleares 1229 es parte de la reconquista cristiana en el marco mediterráneo

5. El operativo de reconquista del reino islámico de Mallorca técnicamente, por la naturaleza insular del objetivo, fue un operativo táctico de expansión marítima mediterránea; pero políticamente, por su etiología, sólo adquiere pleno sentido -como empresas que se potencian y complementan mútuamente- de reconquista por la Cristiandad de las tierras peninsulares hispánicas y del espacio mediterráneo occidental liberándolos del poder del Islam. El operativo de reconquista del espacio islámico balear sólo es inteligible vinculado en el contexto de la confrontación Islam-Cristiandad, en la que se inserta como componente principal.

La estrategia de recuperación del Mediterráneo occidental, iniciada en torno al 800 , se desarrolló en las siguientes fases:

a) Erradicación entre los años 801 y 1005 por la Cristiandad de los enclaves costeros sometidos al Islam (reconquista de Barcelona y de los lugares del litoral de Provenza y de Regio Calabria).

b) Dominio entre los años 1016 y 1101 del área marítima tirrena estableciendo y consolidando bases litorales cristianas en el litoral de Cerdeña, Córcega y Sicilia.

c) Reconquista entre 1229 y 1235 del espacio marítimo balear, lo que comportó la reconquista de Mallorca y de Ibiza y el sometimiemto de Menorca bajo el protectorado de Jaime I el Conquistador.

d) Recuperación entre 1234 y 1244 del litoral de los reinos islámicos de Valencia y de Murcia. El histórico proceso de recuperación por la Cristiandad del Mediterráneo occidental culmina con la larga pugna por el dominio del Estrecho de Gibraltar que se resuelve circa 1340 (6).

La recuperación del Mediterráneo occidental es un proceso histórico que se desarrolla durante medio milenio.

6. El desarrollo de la estrategia de recuperación por la Cristiandad del espacio peninsular hispano y del dominio sobre el Mediterráneo occidental 
estuvo condicionado por las mutaciones históricas que se producen a partir del siglo IX, objetivadas en los siguientes factores:

a) El crecimiento demográfico de la Cristiandad europea. Benet valora un aumento de unos 15 millones de habitantes (de unos 45 millones hacia el año 1000 a unos 60 millones hacia el año 1200), lo que significa un crecimiento vegetativo de un 0'16 por 100 anual y una media ponderada de crecimiento de unos 75000 habitantes/año en dicho período cronológico. Tal crecimiento asentó las bases para el desarrollo económico.

b) El desarrollo económico de la Cristiandad europea. Le Goff interpreta que la recuperación se inició en el sector primario; recuperación manifiesta en lo que denomina con cierto énfasis "revolución agraria", que actuó como locomotora determinando como una dinámica de cadena que arrastró a los demás sectores económicos. El crecimiento agrario generó condiciones favorables a la reactivación del sector artesano, en especial de las manufacturas de pieles, cueros y tejidos; lo que a su vez incentivó el desarrollo del sector terciario, al aumentar el tráfico terrestre y sobre todo el marítimo.

c) El sentimiento de solidaridad cristiana mediterránea. Nicolau D’OIwer interpreta que la conquista de las islas Baleares por Cataluña se demoró por la postura de Génova y Pisa "tàcitament d'acord en no deixar pendre peu a Mallorca a un tercer, mes i tot si aquest es el comtat de Barcelona".

Es posible que Nicolau D'Olwer sobrevalore las rivalidades comerciales entre Génova, Pisa y la Corona de Aragón, que en la segunda mitad del siglo XII no eran relevantes, inducido por el relato de Bernat Desclot según el cual, en torno a 1226, los genoveses y pisanos residentes en Mallorca alentaban los recelos del walí, "per ço que (ells) -razona- poguessen mills comprar e vendre llur mercaderies e que catalans no poguesssen anar per mar"

En 1229 las relaciones no estaban tan tensas como lo estaban cuando Desclot escribe su Crónica. La Crónica Real, más cercana a los hechos, no se hace eco de la mentada incidencia. $Y$ es del caso recordar la afirmación de Gonçal de Reparaz referida al siglo XII: "En realitat els comerciants estrangers que posaren Barcelona en contacte amb el món mediterràni eran gairabé exclusivament pisans i genovesos", 
Pienso que, habitualmente, en los siglos $\mathrm{X}, \mathrm{XI}$ y $\mathrm{XII}$ sobre los intereses político-económicos contrapuestos predominaron los sentimientos de solidaridad cristiana frente al Islam y que en la Cristiandad obraba la conciencia de un enemigo común ante el cual importaba articular, llegada la ocasión, bajo el aliento del Pontificado, un frente operativo común, materializado en el espíritu de Cruzada.

Apreciados desde esta óptica los eventuales recelos surgidos entre cristianos cada dos por tres sobre valimientos y ventajas comerciales en tierras de musulmanes eran más anecdóticos que categóricos; lo más esencial es el sentimiento habitual de solidaridad manifiesta en el frustrado operativo catalano-pisano contra Mallorca en 1115 y en la decisiva contribución de la flota de Génova en la conquista de Almería en 1147 y de Tortosa en $1148(7)$.

7. El operativo Baleares se realiza en 1229 al socaire del proceso de desintegración almohade, notorio desde 1212, que brindaba -por el quebrantamiento del poder islámico que comportaba - una coyuntura altamente favorable a la reconquista hispana; amparado en la filosofía que comportaba la toma de tierras bajo soberanía de infieles no como apropiación abusiva sino como restauración del dominio legítimo que correspondía a la Cristiandad sobre las mismas; y de acuerdo con el convenio de Cazola de 1 de abril de 1179 y del pacto de Barcelona de 23 de diciembre de 1228 .

La desintegración almohade determinó, de resultas de la anarquía política generada, un vacío de poder en Africa, sobre todo en Berbería, y en al-Andalus y en el archipiélago balear y el vacío propició la recuperación del reino de Mallorca al amparo de la filosofía que interpretaba la reconquista como restauración del dominio legítimo se apoyaba en la consideración -ya manifiesta en la Crónica Mozárabe del año 754- de que la "pérdida de España" significó una usurpación ilegítima y abusiva del Islam; por lo que la Cristiandad hispana al recuperar España no sólo asumía una responsabilidad histórica sino que ejercía su derecho a reponer por la fuerza su soberanía sobre tierras usurpadas ilegítimamente por la fuerza por el Islam. La Cristiandad hispana entendía que con la reconquista recuperaba tierras que fueron suyas arrebatadas por el Islam. En dicho marco conceptual corresponde enmarcar la reconquista cristiana de las Baleares.

El operativo Baleares 1229 se efectúa en el marco de lo establecido en el Tratado de Cazola de 1 de abril de 1179 concluido entre Alfonso VIII de Castilla y Alfonso II de Aragón sobre el reparto entre ambas Coronas de la recuperación de áreas peninsulares de reconquista de territorios bajo 
soberanía islámica (Hoc est convenientia facta ... super divisione terre lspanie. Dividunt namque interse terram Ispanie hoc scilicet modo...).

En el Tratado no se menciona expresamente el espacio balear; pero es asumible que tácitamente se le incluye como pertenencia de lo que fue reino islámico de Denia, del que durante cierto tiempo formó parte esencial; reino de Denia vinculado en el Tratado con sus pertenencias al área de reconquista propia de la Corona de Aragón (Et Deniam et totum Regnum Denie cum omnibus pertinentiis heremis et populatis sicut tendit et ducit portus usque ad mare...).

El pacto entre pares, entre iguales, de Barcelona de 23 de diciembre de 1228 ratificado en Tarragona el 28 de agosto de 1229, concluido entre Jaime l, como promotor de la empresa Baleares, y los magnates eclesiásticos y seglares que se comprometen a intervenir en la misma, pacto abierto en condiciones de paridad a cuantos quisieran participar (omnes homines de terra nostra et aliunde venientes que hoc jurare voluerint et venire nobiscum in viaticum supradictum -ad insulas Baleares), se propone recuperar el espacio balear expulsando a los sarracenos que lo ocupaban (profisci ad insulas Maioricas, Minoricas, Eviçam et alias insulas que vocantur generaliter Baleares ad expugnandas inde barbaras nationes ... et terras sarracenorum) (8).

3. En la política de Jaime I no obra la querencia a la expansión mediterránea.

8. El operativo Baleares 1229 se practica desde la mentalidad y la dinámica militante de cruzada cristiana contra infieles. Al efecto, Gregorio IX -bula de Perugia de 12 de febrero de 1229- designa legado pontificio en España al cardenal de Santa Sabina para que otorgue las indulgencias acostumbradas a los que participen en la campaña contra los sarracenos que preparaba el rey de Aragón. ¿Qué indulgencias? Se precisan en el breve de Perugia de 12 de noviembre del mismo año sobre la predicación de la cruzada en la diócesis de Arlés y de Narbona: todas las indulgencias que suelen otorgarse a los que participan en las cruzadas para liberar Tierra Santa (IIlam eis indulgentias concedendo que concedi solet subvenientibus -tam in personis quam rebus Terre Sancte).

En aplicación del concepto de guerra santa y del espíritu de Cruzada Gregorio IX expidió -Perugia 13 de febrero de 1229- mandato a los magistrados municipales de las ciudades marineras del litoral comprendido entre 
Pisa y Marsella -que disponían de efectivos navales- para que prohibieran a sus naturales el suministro de armas, caballos, naves, víveres y, en general, de cualquier producto vedado a sarracenos y, en particular, a los saracenos de Mallorca; advirtiendo que los que les suministraran dichos productos -clasificados como materias de guerra prohibidas-incurrirían en la excomunión ordenada por Alejandro III en el cánon 24 del III Concilio de Letrán de 1179.

Desde el mismo espíritu de cristiandad militante el expresado papa -breve de Letrán de 23 de diciembre de 1230-, con el propósito de promover la repoblación cristiana de Mallorca facultó al arzobispo de Embrun, en Provenza, para que dispensara a los diocesanos que en remisión de sus pecados participaran personalmente en la repoblación de Mallorca y de las tierras restituidas al culto de la Cristiandad (Majoricas et alias terras diu a sarracenis detentas invasas restituit cultui christiano), o coadyuvaran con dineros o productos a dicha repoblación, las mismas indulgencias que gozaban los que aportaban subsidios a lugares de Tierra Santa (9).

9. No hay indicios documentales de que en la política de Jaime I obrara la mentalidad inherente a la expansión marítima. $Y$ tampoco hay indicios de que dicha mentalidad obrara en los magnates que contribuyeron mayormente a la realización del operativo Mallorca 1229, aunque el operativo fuera táctica y técnicamente un objetivo marítimo en el que la flota constituía un componente esencial, sine qua non; no un componente auxiliar como el desempeñado por la flota del Común de Génova en la operación Almería 1147 o en la de Tortosa 1148.

Lo que se verifica en las fuentes cronísticas y documentales, a las que hay que atenerse, es la mentalidad operante de cruzada. Lo rei -relata Desclot- mes un cordonet que tenía e-feu-ne una creu e dix al cardenal - de Santa Sabina- que la li cosis.

En las Cortes celebradas antes en Barcelona en diciembre de 1228 el arzobispo de Tarragona, según refiere la Crónica Real, manifestó en relación a la propuesta de reconquistar Mallorca: Aquest pensament és a honor de Deu e de tota la cort celestial. Y el obispo de Barcelona, según el relato, le dice al rey: Vós sots fill de Nostre Senyor quan volets perseguir los enemichs de la fe e de la creu e per aquest bon proposit haurets lo regne celestial.

Lo que se evidencia en los relatos cronísticos coetáneos -Crónicas de Jaime I y Bernat Desclot- es la clasificación de la empresa en el contexto 
conceptual de la guerra santa contra infieles. La Crónica de Jaime I aporta reiterados testimonios. Yo vaig en aquest viatge per exaltar la fe que vós -Nostre Senyor- nos havets donada e per baixar e detruir-invoca el rey durante la travesía de Salou a Mallorca- aquells que no creuen en vós. Antes, en Lérida, el monarca había proclamado: Mon cor és que pas a Mallorca a honor de Déu e de la Crestiandat.

Luego, aludiendo el asalto de la ciudad de Mallorca practicado el 31 de diciembre de 1229, la expresada Crónica comenta: E segons que els sarrains nos contaren, deien que viren entrar primer a cavall un cavaller blanc ab armes blanques; e aço deu ésser nostra creença que fos Sant Jordi, car en estories trobem que l'han vist en batalles de crestians e sarraïns moltes vegades. San Jorge, versión aragonesa de Santiago, tampoco en esta ocasión, faltó a la cita en la versión taumatúrgica casi tópica de San Jorge o Santiago mata moros (10).

10. Para Jaime I, en efecto, al margen de la lasitud de sus comportamientos en su vida privada, durante y luego de su matrimonio con Violante de Hungría, al enviudar en 1251, la salvaguardia de la paz entre los príncipes cristianos y el mantenimiento de la ideología de cruzada constituyó uno de los ejes maestros de su política exterior.

"Entre Occitania i la reconquesta Jaume I -explica Ferran Soldevilas'havia decidit per la reconquesta". Y Francesco Giunta manifiesta. "L'idea di una crociata in Terra Santa esula dalla forma mentis aragonese... II fenomeno della reconquista si presenta con carattere politico-religioso... e Giacomo I é figlio del suo tempo".

Cumplidos con la reconquista de los reinos de Mallorca y de Valencia y con el apoyo prestado a Castilla en la reconquista y consolidación del reino de Murcia los objetivos de su política peninsular, Jaime I piensa por lo menos desde 1264 en culminar su obra política realizando la cruzada a Tierra Santa, a pesar del desvío entonces del Pontificado. En réplica a sus demandas de patrocinio, "lo Sant Pare -escribe Francesch Carreras Candi aludiendo a la carta de Clemente IV datada en Viterbo el 16 de enero de 1266- li deya ab la més gran energía, que lo Crucificat no rebría tal obsequi d'aquell que per segona vegada l'estava crucificant ab incestuós amancebament. Lo papa no volia donar cap auxili a Jaume I si ell abans no allunyava del seu costat a Berenguela Alfonso".

En 1269 Jaime I intento llevar a cabo en solitario su proyecto de cruzada -el convoy zarpó de Barcelona el 4 de septiembre- con el desafortu- 
nado suceso, desmantelada la flota por un temporal, conocido. No obstante, el monarca persistió en su propósito de promover la cruzada a Tierra Santa y defendió personalmente su propuesta pro-cruzada en el concilio de Lyon de 1274. Sólo entonces, en el avanzado otoño de su vida, ante la postura reticente del papa, de los obispos y de los príncipes cristianos, se avino a la renuncia. Lo relata en tono arrogante su Crónica:

"E sobre aço, llevam-nos e isquem de fora-abandonó la Sala donde se celebraba el Concilio- ab nostra companya e dixem-los: Barons, anarnos-em podem, que ui-que hoy-es honrada -con su propuesta al Concilio -tota Espanya" (11).

11. Las fuentes y los hechos evidencian que Jaime I no compartía y que ni siquiera consideró la política de expansión mediterránea, que acaso obraba como proyecto incierto en la mente y en los comportamientos de su primogénito el infante Pedro.

De haber compartido la línea política de expansión mediterránea son inexplicables las previsiones sucesorias que adoptó prontamente en 1242, reiteradas en 1248 y en 1251 y confirmadas en su testamento de 1262 ratificado en 1272 textualmente; previsiones que comportaban el reparto -ajustado al derecho sucesorio aragonés- de los territorios de la Corona de Aragón entre los infantes Pedro y Jaime y la constitución del reino de Mallorca como ente político independiente de pleno derecho desvinculado de la Unión de la Corona de Aragón.

Dichas previsiones sucesorias, largamente meditadas y tesoneramente mantenidas, no eran compatibles con la promoción de una línea política de expansión mediterránea dada la función logística y estratégica del área balear, núcleo territorial principal del reino de Mallorca, en el contexto del Mediterráneo occidental. Jaime I no sólo no compartía sino que era adverso a la política personal del infante Pedro -casado con Constanza de Suabia- por el riesgo que podía comportar de confrontación con Carlos de Anjou, susceptible de poner en trance de quiebra lo que constituía para Jaime I el objetivo substancial: salvaguardar la paz entre cristianos.

Al contemplar el desarrollo de la política exterior de Jaime I en el último tercio de su reinado se observa que en el ámbito peninsular las coordenadas maestras pasan por la cooperación con Castilla para resolver la difícil situación planteada por la presión de los benimerines y los alzamientos sarracenos en Andalucía, Murcia y Valencia; en el espacio transpirenaico por la conciliación con la Corona de Francia y con los Anjou en el 
marco establecido en el Tratado de Corbeil en 1275; y en el contexto mediterráneo por la querencia a la promoción de la cruzada contra infieles a Tierra Santa.

\section{La expansión mediterránea se inica episódicamente con Pedro I/I de Aragón}

12. Al óbito de Jaime I en 1276 sus previsiones testamentarias se cumplieron: el infante Pedro fue proclamado y reconocido rey de Aragón, rey de Valencia y conde de Barcelona, y el infante Jaime rey de Mallorca y conde del Rosellón y de Cerdaña; pero, de inmediato Pedro III de Aragón, desde la postura prepotente que le otorgaba la superioridad de sus recursos humanos y económicos -que cuadruplicaba ampliamente los del rey de Mallorca-, desarrolló una política encaminada al acoso y aislamiento de su hermano Jaime de Mallorca, con miras a romper la legalidad asentada en las disposiciones testamentarias, y a intervenir en Sicilia para desbancar a Carlos de Anjou alegando derechos dinásticos dimanantes de su matrimonio con Constanza de Sicilia, alentando encubiertamente con sagaz habilidad el rechazo casi generalizado que la dominación angevina -la política angevina- suscitaba entre los sicilianos.

El ambicioso proyecto político de Pedro de Aragón conducido con talento, audacia, secretismo, capacidad resolutiva y sentido de la oportunidad se materializó en 1282 al adueñarse de Sicilia aprovechando las Ilamadas Vísperas Sicilianas. Con ello puede asumirse que se inicia la expansión marítima de la Corona de Aragón, no de consenso con el Pontificado sino allanando un territorio puesto precisamente bajo la protección y el vasallaje de la Santa Sede. Allanamiento impensable desde los presupuestos políticos de su padre Jaime I.

Secuelas inmediatas: ruptura con Francia y con el Pontificado, pronunciamiento por el papa Martín IV -hechura de la Casa de Anjou-, del entredicho contra Pedro de Aragón y sus súbditos de la Corona de Aragón y apertura de una fase caliente de altas tensiones mediterráneas sólo aminoradas trece años después al concluirse en 1295 por imposición del Pontificado el Tratado quíntuple de Anagni entre el papa Bonifacio VIII, Jaime II de Aragón, Felipe IV de Francia, Jaime II de Mallorca y Jaime II de Anjou rey de Nápoles (12).

En conclusión puede asumirse que la Corona de Aragón inicia su expansión mediterránea no en 1229, en la cruzada de Baleares, sino en 1282 , con el allanamineto de Sicilia. 
13. La denominada expansión de Cataluña a juicio de Joan Reglà alcanza su "època daurada" en el reinado de Pedro el Ceremonioso. Reglà rememora el sentir de Rubió i Lluch: "Com els Cèsars romans, Pere el Cerimoniós havia realitzat el somni de l'Imperi en el Mare Nostrum, amb una projecció territorial que cap monarquia europea lograria fins als nostres dies". No obstante, después, Reglà matiza: "L'època daurada de l'expansió catalana s'esgota en la segona meitat del segle XIV".

Don Ramon d'Abadal considera que con Pedro el Ceremonioso comienza la decadencia política de Cataluña dado que en coyuntura histórica poco propicia, lastrada por el declive demográfico y las crisis financieras, llevado de su "vanidad histórica" incurrió en el error político de imponer una política exterior de "prestigio decorativo" impulsado por el "supremo motivo espiritulal" de alcanzar "la grandeza de su Casa", sin reparar en la desproporción que obraba entre los limitados recursos disponibles y los objetivos que con la política de prestigio se proponía alcanzar.

Don Ramon d'Abadal interpreta que Pedro el Ceremonioso hubiera podido eludir la guerra con Castilla de haber practicado la misma política de prudencia y moderación que aplicó en sus cautelosas relaciones con Francia. A su entender la guerra con Castilla significó "para Cataluña no sólo un paro sino un retroceso de su poder marítimo", y que la "ofensiva naval de 1359 contra Barcelona señala el inicio de la potencia naval castellana que no tardaría en manifestarse en el golfo de Gascuña"; y que el hecho de que dicha ofensiva castellana de 1359 "no terminara en desastre demostraba que el poderío catalán en el occidente mediterráneo podía ser afrontado por una marina castellana".

Concluye d'Abadal que con la política de "vanidad histórica" de Pedro el Ceremonioso "el dominio marítimo de Cataluña -al que debía hasta entonces en buena parte sus éxitos- entraba en su ocaso". Al margen de ella la perseverancia en mantener a destiempo, contra corriente de las circunstancias, una política a ultranza de prestigio indica que en la autocracia de Pedro el Ceremonioso y la megalomanía y desplante solían privar sobre la sensatez y el pragmatismo.

La financiación de la política calificada por d'Abadal como de "prestigio decorativo" al servicio de su "vanidad histórica" acarreó, según se indicará (parágrafo 51), desmesurados costos y la factura de lo que cierta historiografía denomina expansión de Cataluña la pagaron todos los reinos de la Unión de la Corona de Aragón sometidos a una política fiscal depredadora. 
Pedro el Ceremonioso conocía la precariedad de la situación, pero mantuvo impertérrito el rumbo de su costosa política cuando los tiempos requerían un cambio, un golpe de timón; lo cual le acredita como político paradógico e inquieto, acaso con habilidad para vender ilusiones, pero no como político avisado y menos como hombre de Estado (13).

5. Con Alfonso el Magnánimo se potencia la expansión mediterránea de la Corona de Aragón

14. La interpretación de Ferran Sodevila que contempla el Compromiso de Caspe "com una mena de suicidi nacional", pues conllevaba "el renunciament dels catalans a Ilur pròpia dinastia"; contrasta con la Pere Tomich, "cavaller de Gavà", considerado por sus contemporáneos como "honorable e prudent històric", que entendía la "història com lum de veritat e maestra de la vida" y que, desde su experiencia coetánea del Compromiso en sus Històries e Conquestes dels reys d'Aragó e dels seus antecessors los comtes de Barcelona, elaboradas en 1448, presenta a "don Ferrando de Castella" como "rey de Aragó e comte de Barcelona elegit per la terra" y, obviando juicios de valor, concluye:

"Les IX persones -en lo castell e villa de Casp-donaren los Regnes e Principat per justicia al infant don Ferrando... Tots los Regnes e Principat hagueren lo dit infant per lur Rey e Senyor".

Ferran Soldevila estima que como secuela de la resolución adoptada en Caspe "l'obra d'assimilació - ¿cultural?- no es faria, doncs, en benefici de Catalunya sino de Castella"; y considera que tras Caspe la expansión mediterránea se desnaturaliza. Las esencialidades de su pensamiento, por imperativo de método, se sintetizan en las siguientes formulaciones:

a) Se impone una nueva concepción imperialista

- "Ferran d'Antequera es el primer governant castellà que es troba en la posibilitat de desplegar una política imperial... però el seu perill ja sembla insinuarse en la mateixa rapidesa i extensió amb qué vol ésser desplegada: ¿No esdevindrà excesiva en els seus objectius?

-"Aquests (objectius) ampliats seran els camins que seguirà la política d'Alfons el Magnànim... La major part de les ambicions d'Alfons no eren noves dins la història de Catalunya. Per aixó ha pogut ésser dit que Alfons el Magnànim havia volgut continuar la política tradicional de Catalunya. 
Però si aixó és cert en quant a la major part dels objectius... no hi és (en) quant a la simultaneitat, l'extensió i l'intensitat amb què va perseguir-los, (en) quant a l'esforç esgotador que va reclamar als seus regnes, (en) quant a l'esperit, i finalment, del seu imperialisme"

-"La dinastia castellana en pendre el lurs mans la política imperial de Catalunya hi havia dut una nova concepció $i$ uns nous metodes... Alfons no era gayre més estranger a Nàpols que a Catalunya. L'apellació efectiva de la terra natal, el desitg dessinteressat de fer-la gran i benaurada -dichosano podían ésser sentits per Alfons respecte als seus regnes ibèrics".

-"Adhuc la part positiva i admirable de l'obra i de la figura del Magnànim, no pot guanyar el nostre entusiasme perquè tambè hi trobem resultats que es girent contra el desplegament -desarrollo- de Catalunya".

b) La Corona de Castilla suplanta a la Corona de Aragón.

- 'Les guerres d'Italia son menades, pròpiament, no pels regnes catalano-aragoneses sinó pels de la Corona de Castella; son castellans en llur major part els rumbosos exèrcits, adhuc els forts estols".

- "La suplantació és gairebé completa... I el convenciment de que la nova conquesta de Nàpols - per Ferran el Catòlic- es feta per i per a Castella errela en les mentes castellans fins a un tal punt que Felip d'Austria em pendre el títol de rei de Castella pretendrà que Nàpols pertanya a aquella Corona".

\section{c) La catalanización de la Corona de Aragón se desacelera}

- "La llengua catalana s'havia estés per totes les ribes de la Mediterrània hi era una de las més conegudes de l'època i havia iniciat també sensiblement la sua penetració a Aragó on el llenguatge escrit n'havia acceptat termes i girs, on nobles i prohoms la parlaven i escrivien, on n'hi havia fins i tot que, a voltes, es consideraven catalans".

- "Catalunya, si el curs normal de la seva existència no hagués experimentat la desviació que aleshores ja l'amenaçaba... hauria estat un dels pobles on la influència del Renaiximent hauria arribat més aviat a plenitud. Literatura, art, ciència, estructuració política, avançament cap a una més forta i concient unitat de les terres catalanes, afermament dels dominis maritims (de la seva vida i del seu Imperi) tot hauria estat afavorit". 
- "El regne de Nàpols forma part a la fi dels dominis del sobirà de Catalunya .... Amb l'establiment en aquell reialme de families catalanes i valencianes ... No acuden però solament a Nàpols gents dels països catalans i d'Aragó; la cort napolitana fou el centre d'atracció de molts nobles i homes d'armes castellans ..."

- "El català fou, correntment, al costat del llatí i del italià, llenguatje de la cancilleria i fins als 1480 els comptes i cedules de la Tresoreria foren redactats en el nostre idioma. Shi introduï també costums catalanes en el vestir, en les festes, en les danses (14).

15. La política de expansión e intervencionismo en Italia de Alfonso el Magnánimo -que incurrió en notorios errores-, contribuyó a agravar la penuria financiera de los territorios de la Corona de Aragón, y es evidente que sus magnanimidades durante su larga permanencia en Italia, en estancia continuada durante 26 años y sin retorno a los territorios peninsulares de la Corona, incidieron en el incremento de una fiscalidad insaciable.

Es cuestionable la presunta proclividad castellanizante de Alfonso el Magnánimo. Como se ha sugerido, arquetipo del mundo renacentista en que vivió, con sus flaquezas, virtudes y defectos, Alfonso el Magnánimo fue sobre todo un gran apátrida mediterráneo. Ni castellano, ni aragonés, nì catalán, ni valenciano, ni mallorquín, ni italiano. Una personalidad ambiciosa que como otros grandes magnates de la política, de la milicia, de la economía y del pensamiento no se sentía ligado en especial a ningún territorio determinado, acaso porque era como un desarraigado carismático, con indudable carisma entre sus súbditos.

Respecto al fenómeno de la presencia en Italia de hispani, no tiene sentido relacionarlo con la política de Alfonso el Magnánimo en Italia. No sólo está documentada la actividad de hispani en la corte napolitana. Pietro Vaccari ha explicitado la estancia en el Norte de Italia, en Lombardía, en la Universidad de Pavía de maestros españoles ("Benedetto Ispani, Ferdinando Ispani, Giovanni Ispani, Guillielmo Ispani") y de estudiantes españoles a fines del siglo XV. Los maestros impartían enseñanzas de metafísica, teología, derecho civil, matemáticas, medicina y hebreo, con la advertencia de que el más prestigioso era un portugués: el franciscano Gómez de Lisboa. 
No tiene sentido, es una paradoja cerrar la expansión marítima de la Corona de Aragón al instaurarse los Trastámara porque son cabalmente los Trastámara los que la culminan. Alfonso el Magnánimo consolida el dominio de la Corona de Aragón en Cerdeña y en Sicilia; y no es cierto que desatendiera los intereses catalanes en Italia dado que les presta apoyo decidido en Nápoles, como ha significado Mario del Treppo, y en Sicilia, como ha documentado Henri Bresc respecto a las importaciones de tejidos (15).

16. El sentido del imperialismo y los efectos de la política de Alfonso el Magnánimo han suscitado criterios historiográficos divergentes.

Joan Reglà lo contempla como "imperialisme de tipus militar, dinàstic $\mathrm{i}$ de prestigi", contrastante con la anterior "política de mercaders que va posar en marxa un gran imperi ..." Y suscribe la tesis del profesor Dupré Thesseider a tenor de la cual con Alfonso el Magnánimo el reino de Nápoles se convierte en "nucli central -dice Reglà- de l'imperialisme de la Corona d'Aragó a la Mediterrània". Ahora bien, es notorio que la expansión mediterránea desde sus inicios es militar, dinástica y de prestigio.

Ernest Martínez Ferrando comparte el sentir de Ferran Soldevila acerca de las secuelas de Caspe. "Aquest gran desti de Catalunya es frustara ab aquella inconcebible claudicació del poble que fou el Compromis de Casp". Para Martínez Ferrando lo esencial es que la expansión catalana se desvirtúa porque por una parte quiebra el impulso catalanizador, "perdent l'orientació catalanitzadora"; y, por otra, la expansión en lugar de encaminarse a Córcega para catalanizarla y completar el dominio catalanizador de las islas del Mediterráneo occidental se orienta hacia Nápoles y Albania, "terres no assimilables a la catalanitat". Para Martínez Ferrando, como para Ferran Soldevila, la expansión marítima era y tenía que proseguir siendo vehículo de normalización catalanizadora de tierras mediterráneas.

Yves Renouard entiende que la conquista de un reino tan importante como el de Nápoles desnaturalizó el imperio catalán, pero no por una orientación castellanizante sino porque Alfonso el Magnánimo lo organiza apoyándose sobre todo en Valencia ("C'est sur Valence qui montait -afirma- qu'il s'appuiera pour l'organiser"), en tanto Barcelona, desamparada, recurre a reivindicaciones extremistas y a turbulencias revolucionarias que agravarán su crisis económica y social iniciada a fines del siglo XIV; crisis quie Barcelona no había logrado solventar.

Robert Henri Bautier interpreta que con Alfonso el Magnánimo el Mediterráneo llega a ser políticamente catalán ("Politicament le Méditerranée 
-manifiesta- est devenue catalane") y Barcelona uno de los mercados más importante de Europa ("Barcelona continue ses trafics avec l'Orient; ses marchands son parmi les plus actifs à Constantinople, en Egypte, à Rhodes. En fin elle est devenue uno de les places de change les plus importants d'Europe"); aunque la ambición del Magnánimo "en voulant conquérir la Méditerranée entiére", determinó la ruina de la marina catalana puesta fuera de combate en Ponza. Bautier magnifica peregrinamente tanto los logros alcanzados como los efectos regresivos de Ponza, que sólo fueron transitorios.

Mario del Treppo manifiesta que la "conquista aragonese di Napoli" aunque comportó serias exigencias financieras en momentos de dificultades económicas, al mismo tiempo abrió nuevas perspectivas a la economía barcelonesa ("Certo l'impresa di Alfonso non è un incidente evenementiel, ma se ha agravatto certe difficoltà, ha indubbiamente aperto nuove prospettive per l'economia barcelonese"). La crisis barcelonesa más que de la coyuntura internacional derivó de los efectos de la guerra civil de 1462-1472 y de la rigidez de las estructuras económicas y financieras barcelonesas que no se adaptaron a las nuevas circunstancias, en tanto se reconvertían con agilidad y a tiempo las de Génova, Florencia y Venecia.

Francesco Giunta considera que la crisis de Caspe -como luego ha reiterado Henri Bresc-, "no debilita el imperialismo aragonés sino que lo potencia"; que el nuevo rey, Fernando de Antequera, se mostró a la altura de las circunstancias y "dio nuevo impulso a la expansión" proseguido por su hijo Alfonso el Magnánimo y, en lo que respecta a Sicilia, tema de su estudio, tras más de un siglo-desde el Vespro siciliano- de polémicas entre Sicilia y la Corona de Aragón, se cierra el "ciclo del Regnum de Sicilia" y con su vinculación a la Corona de Aragón se abre el "ciclo histórico de los virreyes - no de los reyes- de Sicilia", en el contexto de un proceso unificador que madura desde Alfonso el Magnánimo a Carlos V.

Santiago Sobrequés explica que la política de Alfonso el Magnánimo "abrió nuevas y muy vastas perspectivas al comercio catalán" porque Nápoles era un mercado consumidor de enormes posibilidades a causa de su elevado potencial demográfico. La exportación de paños a Nápoles aumentó a lo largo de la segunda mitad del siglo XV hasta llegar a ser a fines de la centuria un monopolio catalán (16). 


\section{La expansión mediterránea culmina con Fernando el Católico en sus direcciones maestras: Italia y el Norte de Africa.}

17. Si no tiene sentido minorizar la expansión mediterránea promovida por Alfonso el Magnánimo con tan resonantes realizaciones como las implicadas por la conquista del reino de Nápoles, menos lo tiene cerrarla en 1479 cuando Fernando el Católico accede a la Corona de Aragón; porque dicha expansión en sus dos direcciones tradicionales -Italia y el Norte de Africa-, culmina precisamente en el reinado de Fernando el Católico.

Culmina, cabalmente, la expansión mediterránea porque se conjuntan bajo una misma monarquía el potencial humano de la Corona de Castilla que septuplicaba el de la Corona de Aragón (Corona de Castilla aproximadamente siete millones y medio de habitantes, Corona de Aragón como un millón de habitantes) y se suman los recursos económicos de la Corona de Castilla que por lo menos cuadruplicaban los de la Corona de Aragón, bajo una soberanía común, la de la monarquía española, que asume y presta nuevos impulsos humanos y financieros a la política de expansión mediteránea.

La política italiana de Fernando el Católico está ligada a la expansión mediterránea por su temprana condición de rey de Sicilia de 1468 a 1472, aunque su designación respondiera a una argucia diplomática de Juan II, como se ha sugerido; $y$, sobre todo, por las campañas de reincorporación del reino de Nápoles a la Corona de Aragón de 1502 a 1507. El que participaran en dichas campañas recursos financieros, mandos y tropas casteIlanas no altera esencialmente el planteamiento.

El continuador de las Històries de Pere Tomich relaciona concisamente la política italiana de Fernando el Católico. "Aprés don Ferrando apellat Catòlic, rey de Aragó e comte de Barcelona e rey de Castella e de tota Hispanya, lo qual aprés de la devisió de aquell, venint a rompuda e discòrdia ab lo rey Loys de França, ab industria de Gonçalo Ferrandes Cordovès, qui per sas victorias e valerosos actes obtingue nom de Gran Capità, vençuts en diverses batalles los exèrcits françesos e expugnades les fortaleses que per dit rey se tenien, no sens gran gloria -escribe pocos años después de las campañas- per tot lo mon divulgada, obtingueren lo dit regne y lo ajustaren a la Corona de Aragó".

Luis Suárez ha señalado que en 1500 se genera en la política de los Reyes Católicos "un giro radical "materializado en el Tratado del Castillo de Chambord que el 10 de octubre del expresado año cierra las negocia- 
ciones secretas franco-españolas; tratado confirmado por España en Granada el 11 de noviembre del mentado año y en el que se conviene el reparto del reino de Nápoles.

Luis XII renunciaba a sus derechos sobre el Rosellón y Cerdaña; y en el reparto se asignaban a Francia juntamente con el título de rey de Nápoles la tierra de Labor y de los Abruzos; y a España -a la Corona de Aragón-, Calabria y Apulia con el título ducal. Sin embargo, la relevancia del "giro radical" de 1500 estriba en que conduciría -como se manifiesta en las Històries de Pere Tomich- a la incorporación a la Corona de Aragón de la totalidad del reino de Nápoles.

El desarrollo y desenlace de las campañas de Nápoles sorprendió a las Monarquías de Occidente como inesperada revelación. Piero Pieri aduce el comentario de II Giovio, un coetáneo perito de estrategia militar, impresionado por la habilidad y el talento táctico de Gonzalo Fernández de Córdoba, conductor de dichas campañas: "Gonsalvo guardagnó -ganóagli spagnoli, la cui virtù non era ancora conociuta, grande honore nelle cose de guerre".

Piero Pieri, especialista en materias militares, valora las campañas napolitanas de Gonzalo Fernández de Córdoba como germen del arte militar moderno en la logística, en la técnica y en la estrategia ("In Gonsalvo troviamo pienamente el germe sia dell'organica che della tattica e della strategia che elevarono al più alti fastigi -al mayor auge- le armi di Spagna; e lo troviamo già nella guerra 1502-1503 ... fondamentali per la storia dell'arte militare moderno").

La hábil política italiana, con la personal participación de Fernando el Católico en Nápoles en 1506-1507 promovió la reintegración del reino de Nápoles a la Corona de Aragón prolongada hasta el siglo XVIII. Jaime Vicens Vives ha subrayado los efectos de la expansión que promueve Fernando el Católico:

"La potencialidad de Castilla respaldando a los catalanes, permite reinstaurarles en los lugares tradicionales de su comercio, con amplias ventajas aduaneras, primero en Cerdeña, luego en Sicilia y finalmente en Nápoles y Africa Menor. Sicilia, sobre todo, será hasta 1640 coto cerrado de la economía catalana decandente" (17).

18. La Corona de Aragón durante los siglos XIII, XIV y XV con un Islam puesto a la defensiva desarrolla una política norteafricana que no se 
propone ocupar tierras, pues la acción de 1282 de Pedro III en Alcoll fue amago táctico en el marco de un operativo cuyo objetivo final era Sicilia (parágrafo 12), sino recaudar impuestos e instalar colonias de mercaderes pisanos, genoveses y marselleses en las plazas comerciales más importantes (Argel, Túnez, Orán, Bugia, Trípoli, Honein, Arcila, Mazagran, Xerxell, Ceuta, Melilla).

A partir de 1500, coincidiendo con la reactivación de la política italiana, el riesgo endémico del corsarismo -en alza desde 1492- se incrementa y gana en agresividad. Como respuesta a dicho recrecimiento se promueven operativos para dar la batalla a los corsarios atacándoles en sus propias bases. En el cuadro de esta política se toma Melilla en 1497, Mazalquivir y Cazaza en 1505 y entre 1508 y 1510 se someten o se toman e instalan guarniciones en el Peñón de Vélez, Orán, Bugia, Argel y Trípoli. Y el protectorado político-militar se extiende a los reinos de Tlemcem y de Túnez.

En la continuación de las Històries de Pere Tomich, en la parte elaborada en 1519, a una década de las campañas, se alude a las mismas en términos expresivos. "Lo rey don Ferrando ... feu grandissim apparat per conquistar Barbaria en Africa. Assi que ab armada marítima conquistaren los espanyols lo castell de Masalcabir e aprés la ciutat de Orà e sucessivament los regnes e ciutats de Bogia e Tripol, essent capità Pedro Navarro, qui era stat sota capità en Nàpols de Gonsalo Ferrandes Cordobes".

Las Històries se imprimieron en 1534 en la "insigne e noble ciutat de Barçelona per Carles Amorós, provençal, regnant lo invicte Emperador dels Romans don Carles ... a honor de nostra nació catalana". Fernando el Católico no sólo recupera el reino de Nápoles, con participación de tropas y dineros castellanos, para incorporarlo a la Corona de Aragón, sino que se apodera en Africa, entre otras plazas, de Melilla, Orán, Bugia y Trípoli.

19. ¿Qué pretendía Fernando el Católico al promover la campaña africana? En 1505 al ponerse en marcha el operativo había afirmado: "Sólo quiero estar libre de discordias con cristianos para poder seguir esta empresa que he comenzado contra los infieles de Africa". Luego, en mayo de 1510, le escribe al conde Pedro Navarro, principal conductor de las operaciones:

"En estas ciudades -alude a Orán, Bugia y Trípoli- no ha de haber moro ninguno sino que al adelante poblar se han de cristianos, porque non se podrían longuamente conservar si siendo toda Africa de moros, huviere moros en las dichas ciudades. Cuidad que las cosas que no quedaren en 
Africa - manifiesta con criterio realista- folgadamente se puedan sostener, porque sostenerlas siempre con lo de aquá, como agora se face, sería imposible y por tiempo se perderían; y assí no aprovecharíamos lo que agora facemos".

La campaña pretendia convertir Melilla, Orán, Bugia y Trípoli en bases que, eficazmente fortificadas, obraran en el litoral norteafricano como enclaves no de castellanos sino de cristianos de expansión político-económica. En el contexto de dicha política en mayo de 1510 otorgó a Bernat Çalba cónsul barcelonés en Bugia competencias para juzgar litigios de mercaderes de todos los territorios de la Corona de Aragón, extendidas después en julio de dicho año a los mercaderes de la Corona de Castilla a cuyo efecto Çalba fue nombrado cónsul en Bugia de los súbditos de los reinos de Castilla, sin que se observe una intención castellanizadora.

En 1511 Fernando el Católico concedió a los barceloneses libertad de comercio y franquicias de tráfico en las plazas conquistadas de Africa y esencialmente en Argel, Bugia y Trípoli. Privilegio de franquicia extendido a los mercaderes valencianos y mallorquines. $Y$ en 1513 dispuso que el cónsul de Bugia ejerciera su jurisdicción "conforme a las leyes y capítulos del consulado e segund que mejor e más complidamente usa e se faze en la ciudad de Barcelona".

Las mentadas disposiciones se otorgan para que "estuviesen puestas en devido orden y asiento -precisa el rey- las cosas tocantes al comercio y contratación sin la cual no se puede ninguna ciudad ni población conservar". En suma, con la reincorporación del reino de Nápoles y la conquista de las plazas norteafricanas culmina la expansión marítima de la Corona de Aragón bajo Fernando el Católico. Por ello no es racional el habitual esquema cronológico que cierra la expansión mediterránea en 1479 (18).

\section{ETIOLOGÍA E INTERPRETACIÓN DE LA EXPANSIÓN}

1. La tesis de la expansión como realización catalana prevalece en la historiografía contemporánea

20. La Unión de la Corona de Aragón culminaba en 1244 con la reconquista de los reinos de Mallorca y de Valencia el histórico proceso de reconquista -en la parte que le tocaba- de las tierras de España, y ajustado 
con la Corona de Francia en 1257 el Tratado de Corbeil, orienta su expansión a partir de Pedro III de Aragón hacia el Mediterráneo.

La expansión marítima de la Corona de Aragón suele ser calificada por la historiografía como promoción catalano-aragonesa, lo que margina o minimiza la participación de los reinos de Valencia y de Mallorca; y, sobre todo, suele ser interpretada por cierta historiografía como materialización de un proyecto político continuado y coherente promovido por la burguesía barcelonesa, símbolo de las esencialidades de Cataluña, encaminado a convertir el Mediterráneo en un Imperio catalán, lo que margina o minimiza la participación de los reinos de Aragón, de Valencia y de Mallorca en una empresa que fue empresa común de la Unión de la Corona de Aragón.

21. Ferran Soldevila es concluyente al afirmar el protagonismo de Cataluña respecto al operativo Mallorca: "Amb la conquesta de Mallorca, Catalunya no ha conquerit solament un tros del seu territori: ha iniciat tambe la seva expansió mediterrània" (19). En relación a la política de Jaime II de Aragón respecto a Sicilia manifiesta que "la conservació de Sicília unida a Catalunya era una empresa molt més difícil que la conservació de Sicília independent" (20).

La intervención en Grecia en lo que denomina "Gran Companya Catalana" la interpreta como "descabdellament expansiu d'un poble maritim com Catalunya decantat cada cop més ... cap a la formació d'un Imperi maritim mediterrani ...". Resultado de la intervención es la constitución de "Estats catalans de Grècia", ligados a la Confederación marítima formada por Cataluña, Mallorca y Sicilia, "de la que es cap el sobirà de Catalunya" (21).

Tales Estados de Grecia, "catalans per la raça, per l'idioma i per les lleis, que no es trobaven units a Catalunya", abrigaban sin embargo "l'ideal cada cop més afermat ... d'ésser anexats sen-se sobiranies intermedies, directament, a Catalunya", anhelo que alcanzan en mayo de 1380 cuando "llurs precs són escoltats" y Pedro el Ceremonioso promulga la "perpetual i incondicional incorporació a la seva Corona" (22).

A partir de 1327 con la conquista de Cerdeña, "Catalunya esdevé ... senyora de la Mediterrània occidental ... Princeps catalans a Catalunya, València, a les Balears, a Sicília, ducats catalans a Atenes i Neopàtra ... Tunis, Tlemcen i Bugia tributaris, protectorat damunt els cristians d'Orient ... és ben bé el descabdellament d'una política d'expansió destinada a convertir de mica en mica la Mediterrània en un llac català". Se materializaba 
un proyecto dirigido y realizado "pels reis catalans, pels sobirans de Catalunya" (23).

¿Reparos? Quizá el no profundizar la penetración en Africa: "Pot ser és de doldre ... que les nostres conquestes mediterrànies no es decantessin cap a l'Africa en lloch de decantarse cap a Europa, perque als països d'Africa arrabassats als musulmans poblats de catalans ... podien haver esdevengut terres catalanes".

También, si acaso, el que dada "la major fidelitat de Catalunya (i) el seu esperit pacific ... els reis catalans per tal d'apareixer lleials d'avant d'Aragó no dupten, algun cop, a sacrificar interesos molt legitims de Catalunya" (24).

22. Joan Reglà interpreta que los grandes éxitos de mediado el siglo XIII a mediado el siglo XIV corresponden a "l'imperialisme maritim .... que no agradava gaire als aragonesos", promovidos por los mercaderes barceloneses: "sembla evident que el principal motor de l'expansió econòmica dels primers anys del Cerimoniós era el gran comerç barceloní a l'època daurada de la economia catalana a la Mediterrània".

Shneidman considera la expansión como resultas de la alianza de Jaime I con los mercaderes catalanes ("Jaume I humiliat per la noblesa d'Aragó havia format una aliança amb els mercaders de Catalunya"); entiende que la "invasió de Sicília ha d'ésser contemplada en el context de l'expansió econòmica catalana al Mediterràni"; y extraña que la querencia de los reyes de la Casa de Barcelona a titularse reyes de Aragón ("Adhuc quan Pere tractava als seus vasalls catalans ho feia més amb títol de rei d'Aragó que no amb el de compte de Barcelona. Sembla haver-hi una contradicció interna: els comtes-reis s'interessen més pel progrés dels catalans que pel dels aragonesos i, en canvi, prefereixen els titols aragonesos").

Robert Henri Bautier piensa que la expansión mediterránea otorga a la marina y al comercio barcelonés una base territorial y unos recursos humanos superiores a los de las repúblicas italianas, lo que explica el apogeo de Cataluña ("Les catalans prennent en mains l'exploitation économique de la Sicilie ... La conquête de la Sardaigne ... arrachée par les catalans à Pise et à Gèneve leur assure une autre clef de la puissance: carrefoure stratégique, l'île leuer donnera une reserve alimentaire apprèciable et, en outre, leur fournira de l'argent et du corail, monnaie d'echange de gran commerce) (25). 
2. La expansión como realización conjunta de la Corona de Aragón es acreditada por los testimonios coetáneos

23. El lenguaje y sobre todo los conceptos predominantes en la historiografía contemporánea que presenta la expansión de la Corona de Aragón como realización singular de Cataluña, contrasta con el lenguaje y los conceptos de los testimonios coetáneos aportados por cronistas próximos a la expansión que participaron personalmente en la misma o se valieron de fuentes orales o documentales directas e inmediatas.

En relación al operativo Mallorca 1229 la Crónica Real alude en dos oportunidades a catalanes y aragoneses conjuntamente ( $E$ hagueren altre consell ... que manàssem Cort a Lleida de catalans e d'aragonesos.- Meterem als aragonesos d'una part e els catalans de l'altra e la sequia en mig).

Son alusiones excepcionales pues el lenguaje de la Crónica describe el operativo como confrontación de crestians e sarraïns o moros; y, el operativo, como "operativo cristiano realizado por cristianos". Los sarracenos hablan en algaravia y los cristianos en nostre llati, sin que la mención catalán en la acepción de la lengua se emplee en las Crónicas del siglo XIII.

Nostre LLati, en sentido coloquial de romanç, de la lengua romance; y a los sarracenos que lo entienden o se expresan en romance la Crónica Real les denomina sarraïns llatinats (26).

24. La Crónica de Bernat Desclot, elaborada probablemente entre 1285 y 1295, presenta normalmente las confrontaciones Islam-Cristiandad como contiendas entre sarraïns y cristians, sin otras connotaciones. Precisa que tras desembarcar en Alcoll Pedro de Aragón notificó al papa: Hajam presa aqui terra ab honor de Déu e creiximent de tota la Crestiandat. $Y$ que antes de zarpar de Alcoll rumbo a Sicilia los barons de Catalunya $e$ d'Aragó le dijeron a su rey: Senyor pensats de fer tot ço qui honor vos sia que nós vos seguirem mentre que la vida en bast.

Relata Desclot que los almogávares que embarcaron en la flota en el puerto de Tortosa y tras una escala técnica en Menorca continuaron hacia Alcoll para pasar a Sicilia, donde derrotaron a los angevinos, eran catalans $e$ aragonesos e sarraïns. En Tortosa se encontraron altres gents -refiere Desclot- que hom apella "golfins" (e) són castellans e gallegos e gent de la profonda Espanya .... 
Quant totes aquelles gents -Desclot alude a los almogávares y a los "golfins" - foren justades al port de Tortosa el rei-Pedro de Aragón- ne trià quinze millia dels mellors que ell poc saber ... . Estos combatientes de aluvión, de diversas procedencias, combatían al grito de guerra de ¡Aragó! ¡Aragó!

En el encuentro naval acaecido a comienzos de septiembre de 1285, en aguas cercanas al litoral de Rosas-Palafrugell, las galeras reales abordaron a las galeras enemigas al grito de combate ¡Aragó! ¡Aragó! (Ab tant les galeres del rei d'Aragó van tocar les trompetes e los tabals e cridaren a grans crits ¡Aragó! ¡Aragó!

La flota conjunta castellano-siciliana estaba al mando de Roger de Lauria, pero los combatientes de las galeras sicilianas, que también dependían del rey de Aragón, realizaron el abordaje al grito iSicília! Sicilia! ( $E$ los sicilians que ho hoiren-relata Desclot-cridaren ;Sicilia! ¡Sicília!).

También la caballería y la infantería que al mando personal del rey acometió el 1 de octubre del mismo año 1285 la retaguardia del ejército francés entró al combate gritando ¡Aragó! ¡Aragó! (Quant los françesos volgueren anar ell -el rey- féu desplegar la sua senyera e cridar a grans crits ¡Aragó! ¡Aragó!) (27).

Lluis Nicolau D'Olwer ha formulado un cabal elogio del cronista Ramon Muntaner: "Més que en Muntaner ningú no ha estimat la seva comarca -l'Empordà-, més que en Muntaner ningú no ha estimat a Catalunya. Per servir al seu país escriu la Crònica, record de gestes glorioses ... Per aixó, si estimem l'obra d'En Muntaner com una font verídica i com un breviari de patriotisme, estimem ell mateix com un model de catalans i d'homens".

En la Crónica de Ramon Muntaner publicada por Nicolau D'Olwer bajo el título Expedició dels catalans a Orient, Muntaner, que participó en la campaña, explica que los hechos maravillosos tots són imputats e deuen ésser al Casal d'Aragó; y relata que zarparon de Messina al mando de Roger de Flor molts cavallers catalans e aragonesos e dels almogàvers ben quatre milia e tots bons.

Catalanes y aragoneses se identificaban no como catalans sino como francs y como a tales eran conocidos y temidos por los pobladores ( $E$ d'aquella avant fo vençuda tota Romania. E los hagueren messa així la paor al cors que no podie hom cridar iFrancs! „Francs! que tantost no pensa- 
sen en fugir). El grito de victoria de dichos francs era el de ¡Aragón! ¡Aragón! (La batalla fo molt fort e cruel mas a la fin tots los francs llevaren un crit e cridam iAragó! Aragó!).

Encara tenia jo -relata Muntaner mediado el año 1306- el sagell -el 'sello- de la Companya ... en que era lo benuvirat Sant Jordi e les lletres -del sello- deien així: Sagell de la host dels Francs qui regnen lo regne de Macedonia. El espíritu dinamizador de San Jorge opera como voz taumatúrgica de aliento en Gallípoli, en la jornada del 7 de junio de 1305, cuando la hueste, en horas bajas, se sentía abatida. Mas una veu-refiere Muntaner- venc entre nós que tuit cridam: ¡Sant Jordi! ;Via sus! ¡Sant Jordi!, e així prenguem vigoria e anam uit en ells -contra los turcos-e així mateix venceren-se.

Ramon Llull escribe aquel año de 1305: Els crestians tenen un gran avantatge (sobre los sarracenos y los turcos), degut a llurs almogàvers -palabra que en árabe significa devastador- que són soldats de peu ... que poden viatjar gran estona de dia e de nit. Ni ha gran nombre a Catalunya, Aragó i Castella (28).

26. Al analizar el lenguaje de Muntaner al realizar la expedición de los almogávares a Oriente se comprende la afirmación de J.N. Hillgarth: "Los historiadores se han equivocado al ver en la Compañía Catalana (denominación que, por cierto, como se desprende por las citas aducidas, no figura en el relato de Muntaner), como una extensión de la política catalana, cuando en realidad los logros conseguidos por aquélla fueron episodios aislados ... en la historia de ejércitos privados".

Pedro el Ceremonioso cuenta en su Crónica que el 24 de noviembre de 1344 para apoderarse de Puigcerdá urdió una conjura en la que, desde dentro de la villa, agitadores sobornados al grito de ¡Aragó! ¡Aragó! masacrarian y desplazarian a los que al grito de iMallorques! ;Mallorques! se identificaran como leales a su rey, Jaime III de Mallorca.

E hagren hòmens llogats - relata la Crónica- que començaren a repicar. E mentre aço començaven, al colp eixiren de les cases tots armats, cridant: ¡Aragó! ¡Aragó! ab empresa -con la intención-que tothom qui cridàs ;Mallorques! ;Mallorques! fos pecejat (29).

27. La discordancia de lenguaje y de conceptos que se observa entre cierta historiografía catalana contemporánea proclive a presentar la expansión como realización singular de Cataluña, dirigida pels sobirans de Cata- 
lunya, financiada por mercaders catalans y orientada a materializar el proyecto político d'un Imperi mediterràni català, para convertir la Mediterrània en un llac català; y el lenguaje y los conceptos de la Crónica Real en la que Jaime I describe la operación Mallorca 1229 no como empresa catalana sino como empresa de la Cristiandad en la que se enfrentan crestians e sarraïns, es notoria.

Y también es notoria la discordancia respecto al lenguaje de la Crónica de Bernat Desclot, cronista áulico de Pedro III de Aragón (Saberen-els cavallers, e burguesos, e ciutadans, e altres hòmens de viles- que el rei En Pere d'Aragó .... ere mort ... e plaguren-lo més que anc rei que fos en Espanya ... No poría ésser dit lo dol e el desconfort que romàs en la terra), y de la Crónica de Ramon Muntaner que, aunque llevado en su entrañable adhesión, fabula hechos que puedan ensombrecer la imagen del Casal d'Aragó, presenta, presentan ambas Crónicas, la expansión como realización conjunta de ambos territorios de la Corona de Aragón, dirigida por el rei d'Aragó; discordancias en las que incide cierto anacronismo psicológico.

Anacronismo psicológico resultante de la tendencia a aplicar al análisis de acaecimientos de los siglos XIII y XIV mentalidades, sentimientos y aspiraciones arraigadas en la contemporaneidad, extraños a los que vivieron dichos acaecimientos, súbditos de territorios de la Unión de la Corona de Aragón, asentada en la vinculación de cada uno de los reinos a una soberanía común y, sobre todo, en el respeto mútuo a su identidad histórica y a su autonomía como entes políticos institucionalmente paritarios, sin proclividades recursalistas.

Dicha tendencia historiográfica en auge desde el último cuarto del siglo XIX, aunque ligada al movimiento de la Renaixença, al resurgimiento lingüístico y literario catalán, la promueve sobre todo -como ha señalado Mario del Treppo-, la voluntad política de la poderosa burguesía catalana que, desilusionada en su aspiración de asumir la conducción de España, "all'unitarismo castigliano oppone un nazionalismo catalano" (30).

Es la tendencia identificada, de momento, en la versión conceptual Països Catalans; tendencia normalizadora, de querencias tentaculares y notorios apoyos políticos que aminora y devalúa la sustancialidad y amplitud del concepto cultura al identificarla sin más con la lengua, que es uno de los componentes esenciales de la cultura; y esquematiza y homologa dogmáticamente, axiomáticamente, como sinónimos los complejos con- 
ceptos lengua-cultura-nacionalidad y aplica tan peregrina homologación conceptual como psilogismo político-cultural de promoción pancatalanista.

\section{La hipótesis ruta africana/ruta de las Islas no está verificada como intencionalidad operativa}

28. El profesor Jaime Vicens Vives formuló en 1957 sugestivas conjeturas sobre el origen y desarrollo de la expansión marítima de la Corona de Aragón.

Primero se estableció, probablemente, la que denomina ruta de Africa o ruta del oro. "Es muy posible -sugiere- que Mallorca fuera elegida como conquista propiciatoria más en vista de su papel de puente respecto a la costa bereber que al litoral sardo". De esta manera, "la gran arteria del organismo económico de la Corona de Aragón -razona- aspiraba oro de Africa del Norte y lo bombardeaba hasta Alejandría en donde se adquieren las especias que luego serían redistribuidas por el Mediterráneo occidental".

El punto de arranque de ambas rutas -la de oro y la de las especiasera Barcelona y la charnela de ambas rutas Mallorca, desde donde las embarcaciones derivaban hacia el litoral norteafricano, donde embarcan oro del Sudán, esclavos y lanas; o proseguían por la ruta de las islas -por Córcega y Sicilia- hacia Alejandría, para embarcar especias.

Los promotores de ambas rutas fueron los mercaderes catalanes, concretamente los barceloneses, que lograron "superar las vacilaciones de la Monarquía motivadas por dificultades internacionales y crisis internas". La Monarquía respaldó la expansión con lo que la Corona de Aragón "se estableció sobre la ruta de las especias y gran parte de su política estribó en la conservación y defensa de la misma".

Con ello la ruta de las especias se convierte en "la estructura fundamental del gran comercio barcelonés y base del imperialismo mediterráneo o de sus reyes". Era tráfico ventajoso pues "las especias compradas en Oriente con oro barato sudanés y vendidas a buen precio en Occidente, debían rendir saldos compensatorios de los riesgos -acoso de piratas, naufragios, deterioros- que comportaba".

En una segunda fase de la expansión a comienzos del siglo XIV, en torno a 1304, "el establecimiento de grandes manufacturas textiles en Bar- 
celona y de rechazo en el resto de Cataluña", genera excedentes exportables de paños catalanes baratos, de consumo popular, que se venden en los mercados de Cerdeña, Sicilia, y Africa Menor conjuntamente con telas de calidad flamencas y francesas.

A los productos expresados -oro, esclavos, lanas, especias y paños-, se añaden los de la industria del metal y los del coral, "este último -precisa Vicens Vives- monopolio técnico de los catalanas durante la baja edad media y estimable fuente de ingresos a causa de la expansión mundial del coral" (31).

29. Las sugestivas conjeturas del profesor Vicens Vives acerca de la motivación y desarrollo de la expansión marítima mediterránea han suscitado reservas. Mario del Treppo arguye:

- Que antes de que la Corona de Aragón estableciera su dominio militar sobre las rutas de las Islas, la denominada "diagonal insular" -Mallorca, Cerdeña, Sicilia- hacia Oriente, había mercaderes de la Corona de Aragón en Alejandría de Egipto y en otros centros comerciales de Oriente, lo que evidencia que el tráfico de las especias podía ejercerse y, de hecho, se ejercía, al margen del dominio militar de la ruta.

- Que los mercaderes de la Corona de Aragón siguen las huellas de negociantes del Languedoc, de Provenza y de Italia, que trafican con las especias y están asentados desde el siglo XI, tan pronto comienza la expansión económica de Occidente, en los centros comerciales de Oriente, sin que mediara un dominio militar de la ruta.

- Que no está demostrado que la progresiva conquista de las Islas se efectuara bajo presión de los mercaderes barceloneses con el propósito de establecer el monopolio del tráfico; o que dichos mercaderes obtuvieran mayores ventajas luego de la expansión militar de las que obtenían antes, cuando traficaban por iniciativa propia.

Francesco Giunta considera que la expansión marítima de la Corona de Aragón no estuvo encaminada a Oriente con ánimo de dominar el tráfico de las especias, sino a "afirmar su hegemonía política en la cuenca occidental del Mediterráneo", y que los puntos terminales de dicha expansión eran Túnez, Sicilia y la faja costera mediterránea de Italia hasta Génova.

La política mediterránea de la Corona de Aragón se proponía a juicio de Giunta dos objetivos esenciales: 
- Desbancar el imperialismo francés asentándose en Sicilia, poniendo en derrota a los Anjou.

- Eliminar la competencia de Génova en el Mediterráneo, asentándose en Cerdeña practicando una política pro-gibelina y aliándose con Venecia.

Ruiz Doménec conjetura que no es asumible la identificación ruta de las especias/ruta de las islas "debido a que la introducción de un capital requiere antes que nada una transformación mental que vendrá dada por una transformación radical de las estructuras de base", es decir, de las "estructuras agrarias".

J.N. Hillgarth rechaza asimismo la hipótesis sobre la ruta de las especias por considerar que ni la Corona de Aragón estableció dicha ruta ni está demostrado que las especias constituyeran la base del gran comercio barcelonés ni del presunto imperialismo económico de los reyes de la Corona de Aragón.

4. No obró un proyecto político programado de expansión marítima en el siglo XIII, y en el siglo XIV se desarrolló una expansión fragmentaria

30. ¿Puede asumirse que en la Corona de Aragón obró un proyecto político programado para asentar deliberada y sistemáticamente su hegemonía sobre el Mediterráneo? Ferran Soldevila lo asume a las claras al afirmar el desarrollo de una política de expansión imperial encaminada a convertir poco a poco el Mediterráneo en un lago catalán (parágrafo 21); Henri Bautier parece presuponerlo al referirse a la superioridad de los recursos humanos y territoriales de la marina y del comercio barcelonés respecto al potencial de las repúblicas italianas resultante de la expansión marítima (parágrafo 22); y la expansión programada pudiera deducirse como implícita en la hipótesis de Vicens Vives sobre el dominio de la ruta del oro/ruta de las especias por la Monarquía de la Corona de Aragón (parágrafo 28).

Al analizar el desarrollo de la expansión marítima y sobre todo el comportamiento de los monarcas, no puede deducirse la existencia de un proyecto político como programa continuado. No obraba, por supuesto, tal proyecto en la mente de Jaime I, dado que está en contradicción con las líneas maestras de su política exterior, orientadas a salvaguardar la paz entre los cristianos y a activar la confrontación con el Islam (parágrafo 11). 
Tampoco parece que obrara en los propósitos de Pedro III de Aragón. Al analizar su política se observa que desde que accede a la Corona ordena sus objetivos según las siguientes prioridades:

- Sofocar los rescoldos de la revuelta de los sarracenos de Valencia y restablecer su autoridad -la autoridad real- contestada por algunos barones catalanes.

- Aislar política y económicamente a su hermano Jaime II de Mallorca para condicionar su independencia, lo que logró en 1279 al imponerle el tratado de enfeudación de 1279.

- Establecer su soberanía sobre Sicilia, debelando a los angevinos, lo que alcanzó en 1282 al socaire de la revuelta de las Vísperas Sicilianas.

Si Pedro III hubiera abrigado el proyecto de expansión marítima como programa continuado no se comprenden sus previsiones testamentarias, adoptadas antes de iniciar el operativo Alcoll-Sicilia 1282 (testamento de Portfangós 3 de junio de 1282), que reparten los territorios de la Corona entre el primogénito infante Alfonso (reino de Aragón, reino de Valencia, condado de Barcelona) y el segundogénito infante Jaime (condados de Ribagorza y de Pallars); previsiones testamentarias de reparto ratificadas y potenciadas luego en abril de 1284 en lo esencial cuando asigna al infante Jaime el reino de Sicilia desvinculado de la Corona de Aragón.

Pedro III, tan hostil a los repartos territoriales ordenados empecinadamente por su padre Jaime I por considerar que debilitaban el poder de la Corona de Aragón, llegada su hora aplicó la misma política -al desvincular el reino de Sicilia- y la mantuvo con idéntica tenacidad, a pesar de que el reino de Sicilia es tan esencial en el marco de una política de hegemonía mediterránea como el reino de Mallorca.

Tampoco obraba el proyecto político de expansión programada en la mente de Alfonso III de Aragón, porque de obrar una filosofía política de expansión programada no es inteligible su testamento (Barcelona 10 de marzo de 1287) en el que instituye heredero universal de la Corona de Aragón a su hermano Jaime -que reinaba en Sicilia- con la condición expresa, sine qua non, de que renuncie al reino de Sicilia en beneficio de su hermano Federico.

La cláusula de renuncia reafirma la desvinculación del reino de Sicilia de la Corona de Aragón, lo que es contrapuesto a la teoría de la expansión 
como proyecto político programado encaminado a asentar sistemáticamente la hegemonía sobre el Mediterráneo (32).

31. Lo que se constata al analizar la política de los monarcas de la Corona de Aragón del siglo XIII es la operancia del proyecto de Jaime I- reconquista de los reinos de Mallorca y de Valencia- ligado a la tradicional política de reconquista peninsular y mediterránea en el ámbito de la confrontación Islam-Cristiandad; y el proyecto de Pedro III de conquista del reino de Sicilia al amparo de los derechos dinásticos que le correspondían como consorte de Constanza de Suabia.

El proyecto de expansión marítima programada ¿obró en la política del siglo XIV? Vicente Salavert interpreta que a partir del Tratado de Anagni de 1295 "se inicia una segunda etapa de expansión metódica y, en general, tenaz". En dicha segunda etapa en el pensamiento político de Jaime Il la conquista de Cerdeña era parte de proyectos más ambiciosos. "De lo que se trataba -precisa Salavert- es del dominio del Mediterráneo occidental".

Cerdeña tenía que cumplir el cometido de base estratégica de enlace en la ruta de navegación que del litoral peninsular conducía a Sicilia con escalas en Mallorca y en Cerdeña.

32. Mario del Treppo aduce una carta de $\$ 311$-publicada por Salavert- en la que Jaime II de Aragón en respuesta al papa Clemente $V$ que le instaba a promover o a participar en la recuperación de Tierra Santa, argumenta con pragmatismo que la ruta marítima a Tierra Santa comportaba el aprovechamiento de Mallorca, Menorca, Cerdeña y Sicilia no sólo como escalas en la larga ruta sino como bases logísticas de avituallamiento y alistamiento de las tropas necesarias a la conquista de Tierra Santa y de reclutamiento de gentes cristianas que repoblaran Tierra Santa (33).

Lo que con sentido realista propone Jaime II de Aragón como presupuesto a una eventual cruzada a Tierra Santa, implícitamente, puede significar la formulación de un proyecto político tendente a promover el dominio hegemónico del Mediterráneo occidental mediante el asentamiento de dichas islas del dominio de la Corona de Aragón. En este sentido es asumible, en líneas generales, que los monarcas de la Corona de Aragón de los siglos XIV y XV tendieron a desarrollar en lo posible una política que aspiraba a implantar cierta limitada hegemonía insular de la Corona de Aragón en el Mediterráneo occidental. 
Pienso que la expansión no se aplicó ni podía aplicarse como programación sistemática sino como proyecto flexible ajustado al hilo de lo que las circunstancias políticas permitían, según un modelo de expansión fragmentada, como ha apuntado Francesco Giunta, y con notorias vacilaciones pues como ha señalado Hillgarth "sucesivos reyes de Aragón siguieron diferentes políticas y diferentes políticas fueron observadas por el mismo gobernante en diferentes períodos" (34).

5. La expansión la dirige la Corona, no los mercaderes de Barcelona, y en la misma los factores de orden político priman sobre los de naturaleza económica que inciden en la expansión

33. ¿Quién dirige la expansión mediterránea? Yves Renouard es tajante: el motor de la expansión militar y marítima son los grandes comerciantes que arman las flotas, conducen las embarcaciones y otorgan préstamos a los reyes. El centro esencial es Barcelona que concentra los recursos de Cataluña y los proyecta hacia el mar. Los ejecutores de la expansión son ricos burgueses barceloneses como los Marquet, los Mallol, los Gruny y los Plegamans.

La función de los mercaderes barceloneses como motor y protagonistas de la expansión mediterránea la respaldan Joan Reglà que la define como "política de mercaders que va posar en marxa un gran imperi" (parágrafo 16), Ferran Soldevila (parágrafo 21), Shneidman y Robert Henri Bautier (parágrafo 22), Jaime Vicens Vives (parágrafo 28) y, entre otros, pues es interpretación histórica ampliamente asumida, Carles Estepa ('L'expansió de la Corona d'Aragó ... hagué d'ésser també producte d'una expansió comercial que evidentment la presupossa".

Don Ramon d'Abadal recalca, al margen de la mercadería como motor, "la fuerza activa e inconmovible del sector feudal" en Cataluña en la época de Pedro el Ceremonioso y aduce que entre 1378 y 1381 el $38^{\prime} 46$ por 100 de la población catalana (unos 40.000 fuegos sobre un total de 104.000 fuegos) estaba avasallada al gran núcleo feudal catalán y que los ejércitos del Principado debían nutrirse básicamente del mundo feudal laico.

D'Abadal considera que las Cortes de 1283 "constituían la encarnación legal del espíritu feudal del país" y que en las mismas "quedó el Estado consagrado en su estructura feudal"; cuya longeva persistencia en el tiempo no puede ser "sólo hija de las circunstacias sino de causas profun- 
das basadas en la idiosincrasia del catalán medieval: el régimen feudal era el que mejor se adaptaba a la misma" (35).

34. La incidencia de los factores económicos en la toma de decisiones políticas es una constante histórica incuestionable dada la natural interdependencia entre la política y la economía, dado que un proyecto político carente de adecuado soporte económico para desarrollarlo queda en puro verbalismo, en mera entelequia discursiva.

Sin embargo, en tanto no obren investigaciones más puntuales que objetiven el alcance de la incidencia de los agentes económicos y, en este caso, el poder de la burguesía barcelonesa en la toma de decisiones políticas de la Corona, y mientras la incidencia del grupo de poder feudal no esté idóneamente valorada, las consideraciones formuladas sobre el protagonismo de los mercaderes, tan generalmente asumidas, procede entenderlas como elucubraciones, como hipótesis de trabajo, si se quiere luminosas y sugestivas y coherentes, pero no como evidencias verificadas.

Las circunstancias que concurren en el operativo Mallorca 1229 aunque no sean extrapolables pueden ser ilustrativas. El hecho de que la Crónica Real presente como arranque de la operación la información formulada por Pere Martell, ciudadano de Barcelona, cómitre de galeras, en el curso de un almuerzo celebrado en Tarragona probablemente mediado noviembre de 1228, ha inducido a la historiografía a considerar que la conquista se decidió entonces y que en la misma la iniciativa corresponde a la burguesía barcelonesa de la que Pere Martell venía a ser portavoz.

No obstante, lo que se decidió en dicho almuerzo no pudo ser la realización del operativo, ya adoptada, sino la convocatoria de las Cortes reunidas el 20 de diciembre de 1228 en Barcelona para programarlo. El acuerdo de acometer el operativo era anterior según se deduce de una alusión marginal (et post reversionem istius exercitus quem facitis contra Maiorchas) contenida en el pacto concluido en Agramunt el 23 de octubre del mismo año entre Jaime I y la condesa Aurembiaix de Urgel sobre donación al rey con efectos diferidos del condado de Urgel.

La reconquista del espacio balear era tema pendiente por lo menos desde la frustración de la cruzada catalano-pisana de 1115-1116. Convenios sobre dicha reconquista se adoptan sin que lleguen a efecto en 1146 (entre Ramón Berenguer IV y la Comunidad de Génova) y en 1178 (entre Alfonso II y el conde Alfonso vasallo de Guillermo II el Bueno de Sicilia); y en una bula de 1205 Inocencio III faculta la restauración del obispado de 
Mallorca cuando Pedro II de Aragón reconquiste Mallorca cumpliendo la promesa formulada el año anterior, en 1204.

El operativo Mallorca se practica, al final, en 1229 propiciado por las circunstancias históricas concurrentes (fragmentación del imperio almohade, pacificación de las tensiones entre los magnates feudales de la Corona de Aragón, recuperación socioeconómica ya manifiesta en 1225). Y la decisión la adopta la Corona al considerar con acierto que la reconquista del espacio balear era táctica y estratégicamente prioritaria a la reconquista del reino de Valencia, pues la reconquista de Mallorca facilitaría la de Valencia como luego se evidenció.

En el pacto de Barcelona de 23 de diciembre de 1228 concluido entre el rey -como promotor de la empresa-y los magnates que se comprometen a participar en la misma, pacto abierto a todos los cristianos que participaran personalmente o aportando recursos (parágrafo 7), se conviene que todos se beneficiaran paritariamente, sin ventajas, en el reparto de lo que se obtuviera en proporción a lo que aportaran y, al efecto, se nombran en seguida los miembros de la Comisión de Reparto de las rentas y de las tierras que se conquistaran.

35. La Comisión de Reparto cuantificó los bienes inmuebles urbanos y rurales a repartir entre los participantes (rey, magnates feudales, comunidades urbanas, individuos particulares), valorándolos en 13.441 caballerías-módulo, medida cuya equivalencia no consta, y repartió el mentado total -como se informa en el Llibre del Repartiment de Mallorca- entre los participantes beneficiarios que, por imperativos de método, pueden clasificarse convenientemente en los siguientes bloques:

\begin{tabular}{|c|c|c|}
\hline BENEFICIARIOS & $\begin{array}{l}\text { CABALLERÍAS } \\
\text { MÓDULO * }\end{array}$ & COEFICIENTE \\
\hline \multicolumn{3}{|l|}{ - Magnates religiosos y Órdenes } \\
\hline Militares & $2.7311 / 2$ & $20{ }^{\prime} 32$ \\
\hline - Magnates seglares & $4.9881 / 2$ & $37^{\prime} 12$ \\
\hline $\begin{array}{l}\text { - Rey, paborde de Tarragona, } \\
\text { comunidades urbanas }\end{array}$ & 5.721 & $42 ' 56$ \\
\hline TOTALES. & 13.441 & 100,00 \\
\hline
\end{tabular}


La aportación de los magnates feudales representó a tenor de los mentados datos, que pueden asumirse como fidedignos, el $57^{\prime} 44$ por 100 del total de caballerías-módulo asignadas y, por tanto, del total de la masa de bienes inmuebles repartidos.

¿Qué representa la aportación de las comunidades urbanas? Se les asignan incluidas en el reparto del realengo un total de 2.559 3/4 de caballerías-módulo, repartidas entre diecisiéte cominidades urbanas, que equivalen al 19'04 por ciento del total de caballerías-módulo repartidas y al 44 '74 por ciento del total de caballerías-módulo del bloque del realengo.

¿Cuántas caballerías-módulo fueron asignadas a las comunidades de barceloneses, a los burgueses barceloneses? Exactamente 877 1/2 caballerías-módulo que significan el 34'20 por 100 del total repartido entre las comunidades urbanas y el 6'53 por 100 del total de caballerías-módulo repartidas. A la comunidad de marselleses se le asignaron 636 caballeríasmódulo con un porcentaje del 4'73 por 100 del total repartido y del 24'85 por ciento respecto al total repartido entre las comunidades urbanas.

Dichos datos sugieren que la aportación a la reconquista de Mallorca de las comunidades urbanas, de los núcleos burgueses incluida la burguesía barcelonesa fue más bien modesta. $Y$, concretamente, la aportación de la comunidad de Barcelona superó la aportación de la comunidad de Marsella concretamente en sólo 1'8 puntos. A la vista de tales datos pudiera pensarse que la historiografía ha magnificado el protagonismo de la burguesía barcelonesa y el poder económico de dicha burguesía cuando se efectúa el operativo Mallorca 1229.

¿Cuál fue la operación de los magnates y caballeros aragoneses? No es posible determinarla porque su participación en la operación Mallorca se practica sobre todo con mesnaderos del rey y también porque las asignaciones se globalizan en el bloque del realengo y quizás también en el bloque de los magnates seglares. No obstante, de los datos de la Crónica Real se desprende que probablemente participaron 380 caballeros aragoneses, de los cuales 200 intervinieron desde el comienzo de la operación, lo que representa el 29 por 100 de los caballeros que a comienzos de septiembre de 1229 zarparon de Salou rumbo a Mallorca (36).

36. Respecto a la operación Sicilia 1282, "vista a menudo -escribe Hillgarth-como un ejemplo del expansionismo de los comerciantes barceloneses, en realidad los intereses de Pedro III eran puramente dinásticos. En una carta de 1283 a Rodolfo de Habsburgo Pedro ponía de relieve que 
era el "derecho de la reina, su esposa y de sus hijos a Sicilia lo que le hacía aceptar la oferta siciliana ... Cuando la expedición partió -del puerto de Tortosa-sólo Pedro sabía donde iba ..."

Mario del Treppo informa que Pedro III no otorgó a los mercaderes catalanes ningún tratamiento especial en el mercado siciliano; y añade que el primer privilegio se lo concedió su hijo Jaime como rey de Sicilia en 1288 , "sei anni dopo la conquista", lo que interpreta como testimonio de la escasa influencia que el testamento mercantil ejercía a la sazón sobre la Monarquía.

El privilegio de 1288 equiparaba a los mercaderes catalanes en cuanto a tarifas aduaneras y prerrogativas consulares con los mercaderes de la Comunidad de Génova, que eran los más favorecidos, y motivó que se multiplicara el tráfico entre Cataluña y Sicilia que antes del Vespro apenas existía y que luego del Vespro alcanzó importante volúmen aunque no significara un monopolio del mercado siciliano.

También aumentó el tráfico de los mercaderes mallorquines que devengaban a tenor de las tarifas aduaneras de 1312 el mismo derecho -un tarin y diez granos por cada cien tarines del valor de las mercancías importadas o exportadas-, que los mercaderes catalanes y genoveses (ítem si burgenses ipsi a januense, cathalano vel maioricano pecuniam in acomendacionem susceperint ad negociandum vel investendum tam in insule Sicilie ...).

El tráfico con Mallorca no se bloqueó en 1342 pese a las conminaciones de Pedro el Ceremonioso a Luis I de Sicilia para que interrumpiera el comercio con los súbditos de Jaime III de Mallorca, alegando que Sicilia era mercado neutral, "aperto a tute le competizioni mercantili".

37. Respecto a Cerdeña el planteamiento es similar. La iniciativa de la empresa la asume la Corona que considera sobre todo los intereses políticos, el ejercicio de los derechos que asisten a la Corona de Aragón en la denominada cuestión sarda, y la incidencia de la rivalidad con genoveses, pisanos y angevinos.

No está objetivada, sin que ello signifique desmerecimiento de la esencial entidad de los intereses económicos tan estrechamente ligados a los políticos, ningún control o influencia predominante o especial de los mercaderes a los que se otorgó inmunidad aduanera para compensar la 
ayuda prestada a la conquista, situándose en posición privilegiada en el mercado sardo.

"La Corona de Aragón -concluye Salavert- no fue a Cerdeña por motivos puramente políticos imperialistas ni tampoco por razones puramente económicas. En sus tierras ... los súbditos de Jaime II no dejaron de apreciar las riquezas naturales que de ellas -de las tierras insulares- podían ganarse ... en cuanto territorios en los que podrían colocar sus productos y los artículos que sus naves transportaban por el Mediterráneo ...".

No obstante, entiende que "al menos las cabezas rectoras ... hubieron de atribuir el más alto precio todavía a la posición sarda por su condición de base desde la cual dar a aquellas mismas naves la mayor seguridad posible a través de sus rutas mediterráneas" (37).

\section{La terminología Imperio o imperialismo mediterráneo catalán es magnificación contemporánea, extraña a las fuentes coetáneas}

38. ¿Qué se proponía la expansión mediterránea de la Corona de Aragón? Rafael Tasis considera que la política de Pedro el Ceremonioso se orientaba a crear "una federació d'Estats mediterrània continentals i insulars units per lligams dinàstics però tambè per una concepció política i uns interesos comercials". Joan Reglà interpreta que la política de Pedro el Ceremonioso procuraba lo que denomina "reintegració mediterrània", no sólo del Mediterráneo occidental, y que dicha política culmina en 1379-1380 con la incorporación a la Corona de Aragón de los ducados de Atenas y Neopatria.

Vicens Vives que rechaza que el Mediterráneo fuera en algún momento una mar catalana ("La caiguda de la república de Sant Jordi -se refiere al Común de Génova- hauria fet de la Mediterrània occidental una mar catalana. Gènova no fou mai catalana"), considera que, sin embargo, Alfonso el Magnánimo "es comportà gairebè com l'emperador de la Mediterrània, un imperi al servei dels catalans".

Ferran Soldevila manifiesta que en la expansión marítima catalana obraba una "acció imperial", una dinámica imperial y establece la dualidad entre la moderada concepción imperial catalana y la desmedida concepción imperialista catalana, importada por los Trastámara que instaura una nueva concepción y unos nuevos métodos personificados en los sueños 
de imperio mediterráneo de Alfonso el Magnánimo y sus aspiraciones -dice- al dominio de medio mundo, con resultados negativos para Cataluña.

Ernest Martínez Ferrando alude al "últim fulgor imperial de Catalunya"; Joan Reglà refiere a una "política de mercaders que va posar en marxa un gran imperi"; J. Lee Shneidman ha realizado una amplia aportación sobre "L'Imperi catalano-aragonès" y Rubió i Lluch menciona que "Pere el Cerimoniós havía realitzat el somni de l'Imperi en el Mare Nostrum amb una projecció territorial que cap monarquia europea lograria fins als nostres dies" (parágrafo 12) (38).

39. Las expresiones "imperialismo" o "expansión imperialista" o "política imperial" o "imperio" son extrañas al lenguaje y conceptos de las Crónicas y de las fuentes documentales de los siglos XIII, XIV y XV en relación a Cataluña o a la Corona de Aragón.

En una ocasión la Crónica Real alude al feit de l'Imperi refiriéndose al Imperio Romano Germánico. Jaime I se entrevista en 1275 con Alfonso X de Castilla e intenta disuadirle de su propósito de reivindicar ante el papa sus derechos al citado Imperio. Lo relata la Crónica Real: $E$ nós aconsellam-li que per nulla res no hi anás -a las vistas con el papa Gregorio X-, que no era cosa covinent a ell a anar en tan estranya terra ... E no ens vols creure d'aquell consell que nós donat li havíem e anàssen a l'Apostoli ...

En la Crónica de Bernat Desclot no obra mención alguna a Imperio, ni siquiera con referencia a los dos Imperios que existían entonces: el Imperio Romano Germánico y el Imperio de Oriente o de Constantinopla. En la Crónica de Ramon Muntaner se alude con relativa frecuencia a Imperio pero siempre referido al Imperio de Constantinopla. En la Crónica de Pedro el Ceremonioso se nombra en una oportunidad las parts de Romania sinónimo de Imperio de Oriente.

En los Anales de Zurita las nominaciones de Imperio son numerosas tanto respecto al Imperio Germánico -en las variantes Imperio Romano, Imperio Germánico, Imperio Romano Germánico, Imperio de Occidente e Imperio Alemán-, como respecto al Imperio de Oriente- y además en los veinte densos libros que componen los valiosos y voluminosos Anales de Jerónimo Zurita hay una referencia a Imperio Turco, pero ninguna a Imperio o a política imperialista catalana o de la Corona de Aragón.

En la continuación de las Històries de Pere Tomich obra una alusión al Emperador dels Romans Maximilià, lo que al paresent-explica-encara de 
bona edat es corregnant ab llur fill lo invicte Emperador dels Romans don Carles, y otra al rey don Phelip y a la reyna dona Johana sa muller pares del present Emperador dels Romans don Carles (39).

40. La inexistencia en las Crónicas y en las fuentes documentales bajo medievales de referencias a Imperio Mediterráneo de Cataluña o de la Corona de Aragón no es sorprendente sino coherente con la terminología, los conceptos jurídico-políticos y las mentalidades de la época, es decir, en el bajo medievo occidental.

La Cristiandad sólo reconocía entonces los dos Imperios dimanantes de la ruptura del antiguo Imperio Romano: el Imperio de Occidente o Romano Germánico y el Imperio de Oriente o Imperio de Constantinopla, los únicos con legitimidad y ejecutoria histórica que les acreditaba, sin peregrinas magnificaciones, como Imperios.

Los otros entes políticos territoriales soberanos -marquesados, condados, reinos- aunque se integraran como era el caso de la Corona de Aragón en uniones personales vinculándose a la persona de un mismo soberano, y aunque otros reinos se sometieran a su vasallaje, como fue el caso de la Corona de Castilla en tiempo de Alfonso VII denominado el Emperador y coronado Emperador, carentes de legitimidad que a tenor de la doctrina jurídico-política imperante sólo podía otorgar el Pontificado, quedaron reducidos a pura parafernalia formal, vacíos de contenido jurídico que los legitimara.

Salvando excepciones, que no consta que se dieran en la Unión Personal que no Confederación (pues no obraban las indispensables instituciones requeridas por el derecho y por la teoría política constitucional) de la Corona de Aragón, los cronistas, el funcionariado de las cancillerías y también las gentes llanas de cualquier país eran cuidadosos y rigurosos en su lenguaje y aplicaban con propiedad, de acuerdo con la mentalidad jerarquizada de la época, a cada ente político -condado, reino o imperio- el tratamiento y la titulación que le correspondiera al margen de las contingencias de su poder político o de las variaciones de su ámbito territorial. La intitulación condado de Barcelona es ejemplo paradigmático en el seno de la Unión de la Corona de Aragón presidida por el rey de Aragón, por monarcas del Casal d'Aragó en lenguaje de las Crónicas catalanas.

La historiografía que aplica terminológías y conceptos que no se corresponden con los documentados en las fuentes cronísticas y documentales y que contempla el proceso histórico desde ópticas y aspiraciones ope- 
rantes en la actualidad, pero que no concurrían en el pasado historiado, incurre en flagrante anacronismo terminológico y psicológico. Para las gentes de la baja edad media de la Corona de Aragón la terminología y los conceptos que les atribuye cierta historiografía contemporánea resonaría a terminología y conceptos ininteligibles, ajenos y extraños a sus modos de expresarse y a sus mentalidades.

La expresión Imperio Mediterráneo de Cataluña o de la Corona de Aragón en la versión denominada desde comienzos del siglo XX Països Catalans en plural y más recientemente, a veces, País Català en singular, con idéntico contenido y significado político, es una licencia historiográfica de lenguaje, una magnificación historiográfica verbalista, sin rigor, conectada con mentalidades y aspiraciones contemporáneas, activas y militantes, de vocación pancatalanista y asunción sucursalista.

La expresión Països Catalans o País Català acaso pueda ser realidad en el futuro, y es válida en la dialéctica política tendente a afirmar dicho futuro, pero no tiene raíces ni ejecutoria que legitimen la expresión en el pasado. La Corona de Aragón se asentaba en el mútuo respeto a la identidad, autonomía e instituciones peculiares de cada uno de los territorios que como miembros institucionalmente paritarios integraban la Unión Personal, sin asimilismos normalizadores.

41. La expresión "política imperialista" o "imperialismo", aunque no conste en las fuentes cronísticas o documentales bajo medievales de la Corona de Aragón, es asumible y aceptada en la acepción conceptual de proyecto o tendencia de un ente político a implantar su supremacía o hegemonía político-económica o simplemente económica sobre un área o sobre áreas territoriales, o sobre mercados propios de otros entes políticos para quebrantarlos, o para asentar su hegemonía política o económica. Tales expresiones son válidas porque, aunque no obraran entonces en la terminología, obraban en las mentalidades como conceptos, lo que es tan sustancial y categórico o más sustancial y categórico que la terminología.

En el contexto del ambiente de euforia generado por la resonante victoria alcanzada en septiembre de 1285 en aguas del litoral Rosas-Palafrugell por la flota catalano-siciliana al mando de Roger de Lauria sobre la flota francesa, la Crónica de Bernat Desclot relata la conocida anécdota del debate dialéctico habido en Cadaqués entre Roger de Lauria y los emisarios de Felipe III de Francia el conde de Foix y Ramon Roger. 
Los emisarios solicitan una tregua que Roger de Lauria deniega (En Roger respos-los que null temps no hauria treves ab francesos ne ab provençals aitant com viu fos). El conde de Foix, incomodado por la negativa, replica en tono airado, irat e folló, que el rey de Francia tenía poder para armar en un año trescientas galeras, lo que con todo su poder no podía realizar el rey de Aragón, a lo que Lauria contesta con arrogancia:

Senyor ... no vull haver treves ab lo rey de França; e si el rey de França n'arma trescentes galeres, armar-ne -mon senyor lo rei d'Aragócent, sens pus; e quant aquelles cent (galeres) hage armades ... no en tem -que les trescentes galeres de lo rei de França o mil si es vol-, que no gosen trobar ab mi en neguna part.

No sol no em pens que galera ne altre vaxell -dice con gallardía Roger de Lauria- gos anar sobre mar menys de guiatge -sin salvoconductodel rei d'Aragó; ne encara no solament galera ni leny, mas en creu que negun peix se gos alçar sobre la mar si no porta un escut ab senyal del rei d'Aragó en la coa per mostrar guiatge d'aquell rei d'Aragó.

Refiere la Crónica que el conde, oído el desplante, sonrió y tras un breve y, por lo que se deduce, distendido cambio de pareceres, se despidió de Roger de Lauria para regresar a Castelló de Ampurias donde el rey de Francia permanecía por la peste que motivó poco después su óbito (40).

42. La afirmación de que el rey de Aragón podía asumir por entonces la hegemonía marítima obra en un borrador de instrucciones datadas el 23 de mayo de 1293 y elaboradas para que el judío alfaquín Bondaví las comunicara como emisario de Jaime II de Aragón al sultán Otman de Tlemcen.

Objetivo de la embajada: convencer a Otman de que ningún rey ampararle de cualquier riesgo, incluso de sus propios súbditos, que el rey de Aragón con su amistad y su poderío, si Otman en compensación le devengaba un adecuado tributo anual por la protección que le dispensaría.

La embajada no llegó a cabo. Bondaví no fue a Tlemcen. Pero en las instrucciones se le ordenaba que dijera a Otman:

Els soldats de la seva Corona -d'Aragó-, cavallers e infants eran los millors del món y el rey d'Aragó era el princep y senyor més poderós que al món hi havia, especialment per mar. 
La afirmación de la prepotencia del rey de Aragón valía como argumento dialéctico de convicción pero ¿cuál era la realidad? Por supuesto distinta y más compleja. Con más operancia que las naves catalanas, pisanas, francesas o mallorquinas marineaba la flota genovesa; el corsarismo castellano en aguas del Estrecho y desde la base de Cartagena se desplegaba con creciente audacia, lo mismo que el corsarismo portugués; y resurgía el corsarismo berberisco que pirateaba por el mar Balear y por las costas de Murcia, Valencia y Cataluña en conjunción con el corsarismo granadino.

Al margen de los verbalismos jactanciosos de imagen ningún poder, ni siquiera el poder marítimo del Común de Génova, asumía la hegemonía en el revuelto espacio mediterráneo en el que, pese a las conminaciones del papado pro solidaridad cristiana, todos competían entre sí y, llegado el caso, cristianos pirateaban a otros cristianos generándose una cadena inacabable de represalias (41).

43. Al comenzar el siglo XIV desvinculados los reinos de Mallorca y de Sicilia de la Corona de Aragón, ésta quedaba reducida a sus territorios peninsulares (reino de Aragón, reino de Valencia, condado de Barcelona); aunque en la circunstancia más que la desvinculación incidía la tensión de las relaciones de Jaime II de Aragón con su tío Jaime II de Mallorca y con su hermano Federico II de Sicilia.

Tensión Jaime II de Aragón-Jaime II de Mallorca dimanante de la disconformidad del rey de Mallorca con la enfeudación del reino de Mallorca al rey de Aragón como conde de Barcelona impuesta en el tratado de Montpeller de 1279, y de la competitividad comercial entre Cataluña y MaIlorca en las plazas norteafricanas. Tensión Jaime II de Aragón-Federico II de Sicilia resultante del sentimiento de desamparo que abrigaba el rey de Sicilia respecto a su hermano cuya política exterior -apunta Giunta- se concentraba en la preparación diplomática y militar de la campaña de Cerdeña.

La teoría de una monarquía aragonesa de concepción satelital, en cabeza el rey de Aragón, que de tots es cap major, y en su torno y bajo su paternal protección y dependencia, a son manament, los reinos de Mallorca y de Sicilia, obraba en la fabulación de Ramon Muntaner que llevado en su entrañable adhesión al Casal d'Aragó - no obra en su terminología la expresión Casal de Barcelona-, contempla y presenta las relaciones desde la óptica de una solidaridad dinástica que no se correspondía con la realidad. 
En el acaecer real los mútuos recelos primaban sobre los sentimientos de solidaridad dinástica. $Y$ ello le constaba a Muntaner perfectamente informado. Por eso, para instar la necesaria concordia y solidaridad recurre para expresar la fuerza de la unión y que la unión hace la fuerza a la metáfora de la mata de jonc, de la mata de juncos, fácil de desarraigar si se arranca junco a junco pero a duras penas arrancable como mata.

Mata de jonc-explica Muntaner- ha quella força que si tota la mata lligats ab una corda ... e tota la volets arrancar ensems dic-vos que deu hòmens, per bé que tiren, no l'arrancaran ... e de jonc en jonc la trencara tota un fadrí-un niño- de vuit anys, que sol un jonc no hi romandrà.

Corolario de la metáfora: $E$ axi seria d'aquets tres reis que si entre ells havia devision ninguna ne discordia, ço que Déus no vulla, fèts compte que han de tals vehins -alude en especial a Francia- que pensarien de consumar la un ab altre. Per qué es mester que d'aquets pas -de la discordia- se guarden, que mentre tots tres sien d'una valença ... (seran) tots temps sobirans a llurs enemichs (42).

44. ¿Cuál podía ser el alcance del imperialismo, entendido como aspiración a la hegemonía de la Corona de Aragón en los siglos XIII y XIV? Giunta argumenta que si valoran las posibilidades económicas de la Corona de Aragón no es asumible la operancia de un imperialismo político-económico catalano-aragonés que carecía de los recursos necesarios para formular, para desarrollar, un proyecto político de expansión de amplio alcance.

"Non ci sembra possible parlare d'imperialismo -economico e politicocatalano aragonese -razona Giunta- in quanto mancavano le basi esenziali per formulare un qualsiasi programo de conquista a largo ragio". Los éxitos navales de Roger de Lauria en 1285 -manifiesta- se debieron en buena parte a los recursos navales sicilianos que prestaron superioridad a la flota catalano-siciliana sobre la flota angevina y añade que los catalanes sólo alcanzaron prestigio "comme marinai preso i contemporani solo verso la meta del secolo XIV".

45. J. N. Hillgarth piensa que la historiografía, al afirmar la existencia de un "imperialismo" catalán en los siglos XIII y XIV aplica el término "imperialismo" con impropiedad. "Suponer que existió un intento de hacer del Mediterráneo un lago catalán - discurre Hillgarth- nos lleva a imaginar más un Benito Mussolini que un cauto Jaime I con unos determinados proyectos para la idea de una limitada hegemonía en el Mediterráneo occidental". 
En cuanto a la hipótesis de la posibilidad de un "Imperio Catalán" todavía le parece más inexacta. "Un imperio de tal naturaleza -expone Hillgarth-podia haber adquirido una forma real si la Corona de Aragón hubiera realmente contado con los reinos gobernados por las ramas más jóvenes de la Casa de Barcelona, Mallorca y Sicilia". Hillgarth sugiere que acaso los historiadores modernos están influidos por el cuadro de solidaridad dinástica que presenta en su Crónica Ramon Muntaner.

La realidad era distinta. En la realidad, "sólo la fuerte presión francesa y papal fueron los que obligaron a Jaime II de Aragón a restituir Mallorca a su tío -Jaime II- en 1298. Aragón estuvo siempre buscando oportunidades para suprimir la independencia de Mallorca". En la realidad aunque Federico II de Sicilia se mantuvo deferente con su hermano Jaime II de Aragón, "los dos paises observaban políticas distintas". Hillgarth recuerda que en 1327 la Corona de Aragón sólo controlaba de un modo directo -aunque entre incertidumbres y sobresaltos- la isla de Cerdeña.

En la práctica lastraban el desarrollo de un "Imperio mediterráneo catalán" o de un "imperialismo catalán" los siguientes factores:

- La circunstancia de que la Corona de Aragón era constitucionalmente una Unión Personal, sólo vinculados los reinos y condados que la integraban por su dependencia a una soberanía común.

- La economía relativamente subdesarrollada. "A Cataluña -aduce Hillgarth- els preus de les manufactures eren molt més alts que els productes del camp. En el segle XIII Catalunya quedava molt darrera França quant a desenvolupament industrial i no parlem d'Italia i de Flandes".

- El crecimiento de la burguesía no era todavía suficientemente importante y, sobre todo, eran muy limitados los recursos militares y navales de la Corona.

En 1315 las rentas reales de Cataluña ingresadas efectivamente en la Tesorería real importaban 17.000 sueldos del total teórico de 66.000 sueldos que correspondía ingresar. Es decir, la Tesorería sólo ingresaba el 25 '75 por 100 de las rentas porque las restantes rentas estaban hipotecadas.

La escasez de recursos condicionaron la expansión en el Mediterráneo occidental y el que la presencia en Grecia fuera un episodio efímero y aislado. "La flota catalana -comenta Hillgarth- no més penetrà en el Medi- 
terrani oriental quan Roger de Llùria hi piratejà a la decada de 1290, després aliada amb Venècia contra Gènova en 1351 (43)

\section{SOBRE LA FINANCIACIÓN DE LA EXPANSIÓN}

1. La financiación de la expansión es el aspecto menos investigado

46. La financiación, en el desarrollo de un proceso histórico con tantas lagunas de conocimiento y en el que las conjeturas predominan sobre las evidencias, es el aspecto menos conocido, siendo de tanta relevancia, en el contexto de la problemática de la expansión marítima de la Corona de Aragón.

¿Cuál era la procedencia de los capitales que financiaron la expansión? Si el desarrollo del artesanado era todavía mediado el siglo XIII rudimentario en todas las ciudades de la Corona de Aragón, ¿cuál era el nivel alcanzado en las áreas del sector agrario y en las actividades del sector terciario? Como afirmaba en 1962 Yves Renouard el estado de los estudios sobre tales materias no autoriza a formular conclusiones asumibles.

La tesis del profesor Vicens Vives sobre una financiación procedente de capitales aportados por el ejercicio del corsarismo y del tráfico de esclavos está sin objetivar. Y la hipótesis del expresado profesor sobre la posibilidad de que la expansión se financiara con oro albigense importado en Cataluña y en Aragón por herejes del sur de Francia que huyeron de las persecuciones de la Inquisición, es hipótesis que como han apuntado Renouard, Del Treppo, Salavert y, entre otros, Hillgarth, está sin documentar.

Está probado el asentamiento en Aragón, en Cataluña y en Mallorca de albigenses, pero no constan si dichos albigenses eran personas de recursos económicos importantes, ni se sabe que existiera un tesoro albigense y que dicho tesoro afluyera a territorios de la Corona de Aragón (44).

47. Giunta se ha referido a la proverbial fama de pobreza que tenían en Europa la gentes y los reyes de la Corona de Aragón, y aporta el testimonio de un contemporáneo referido al último cuarto del siglo XIII: Gentem Aragonum parvam, nudam corporis et rerum prodigem et ad omne genus laboris pronam et sunccinctam contra opinionem humiliata est. Y la referida de Dante sobre la avara povertà di Catalogna. 
Jaime I relata en la Crónica Real como su padre lo rei Pere (que) fou lo pus franc rei que anc fos en Espanya e el pus cortes, dejó el Tesoro real exhausto pues tota la renta que havia en Aragó e en Catalunya era empenyorada -empeñada- tro als jueus e als sarrains e encara los honors que eren setcentes cavalleries en aquell temps, e nostre pare lo rei don Pere haviales totes donades e venudes de cent trenta en fora. $Y$ aludiendo al año 1214 cuando comienza a reinar indica: $E$ no haviem a un dia quan nós entram en Montsó qué menjar, jsi era la terra destroïda e empenyorada!

La Crónica de Bernat Desclot refiere que el conde de Foix le advirtió a Felipe III el Atrevido en 1285 que Pedro III de Aragón era tan animoso que con 2.000 caballeros suyos podía hacer frenar a 100.000 caballeros franceses, y cómo el rey francés lo tomó a broma: ric-sen e dix al comte que be parien les sues noves quant deïa que Pere d'Aragó, qui era un dels pobres reis del món de terres e d'haver, daria batalla al rei de França... .

Ramon Muntaner recoge la fama de pobreza atribuida entonces en el primer cuarto del siglo XIV, antes de advertir la crisis, a Cataluña. E negù no es pens -comenta- que en Catalunya sia poca província, ans vull que sàpia tot hom que en Catalunya ha comunament pus ric poble que negù poble que jo sàpia ne haja vist per neguna província, si be les gents del món-reconoce- la major part los fan pobres. Ver es que en Catalunya no ha aquelles grans riqueses de moneda de certs hòmens senyalats que ha en altres terres (45).

2. Los subsidios pecuniarios a la Corona recurso esencial de financiación de las empresas expansivas

48. La operación Mallorca, la financiaron como se ha indicado (parágrafo 30 ), el rey, los magnates, las comunidades urbanas y los individuos particulares que participaron en la misma al amparo del pacto suscrito el 28 de agosto de 1229 en Tarragona según el cual lo que se ganara, todo lo que se ganara, se repartiría en proporción a lo que cada cual hubiera aportado a la empresa. Este sistema de financiación no se aplicó a la expansión mediterránea.

Lo cierto es que para la expansión de la Corona, falta de recursos, además de vender e hipotecar rentas y tierras del Real Patrimonio, tuvo que solicitar de todos los territorios integrados en la Unión subsidios pecuniarios, al margen de los que ordinariamente solían devengarse al Tesoro Real. 
Isabel Falcón ha documentado el subsidio pagado por ciudades y villas aragonesas para financiar los preparativos de la campaña de 1282 preparada, se decía, contra moros de Africa y en realidad, como se comprobó a su tiempo, dirigida contra los angevinos de Sicilia: 415.000 sueldos. Y consta la aportación de los obispados de Barcelona, Gerona, Lérida, Tarragona y Tortosa como motivo de la invasión francesa de 1285: 1.094 .0000 sueldos.

Se comprende el malestar social generado por las secuelas de la campaña siciliana manifiesto en la revuelta popular de Berenguer Oller en Barcelona en marzo de 1285 y en las concesiones políticas que Pedro III de Aragón tuvo que dispensar ante la anunciada invasión francesa para obtener la ayuda de sus súbditos molestos y fatigados por la larga contienda: el Privilegio General de 3 de octubre de 1283 a los aragoneses, los Privilegios de diciembre de 1283 a los valencianos y el privilegio de enero de 1284 denominado Recognoverunt Proceres a los catalanes.

De tales concesiones motivadas -explica Rovira y Virgili- por "la situació critica en que es trobava davant la hostilitat del papa i dels reis de França i de Mallorca", las de espíritu más equilibrado, más positivo y de contenido social más avanzado fueron las otorgadas al reino de Valencia; porque el Privilegio General, en que se confirman privilegios y costumbres antiguas, comportó un sistema fiscal opresivo y un sistema económico intervencionista; y el Recognoverunt Proceres significa una imposición de las oligarquías burguesas y feudales e implicó la legalización del estado de los payeses de remensa, al tiempo que se disminuían las atribuciones del rey y de los oficiales reales, lo que incrementó la solidez del feudalismo en Cataluña.

Testimonia el elevado índice de endeudamiento del Real Patrimonio la consideración de que en 1315 de los 24.000 sueldos pagaderos anualmente a la Corona por la aljama de judíos de Barcelona la Tesorería sólo ingresaba 1.000 sueldos, es decir, el 4'17 por 100 del total pagadero; y de los 43.000 sueldos que satisfacían anualmente a la Corona las aljamas aragonesas sólo ingresaban en Tesorería 1259 sueldos, o sea, el 2'93 por 100 del total pagadero. La restante renta de dichas aljamas la Corona, para salir de apuros las había enajenado o hipotecado (46).

49. Para la conquista de Cerdeña se armó en 1323 la flota más grande reunida por la Corona de Aragón en los siglos XIII y XIV: cincuenta y tres galeras. 
Contribuyeron en la aportación de galeras los territorios litorales de la Corona, aunque la mayor parte -el 37'34 por 100 del total- lo aportó el reino de Mallorca, desvinculado entonces de la Corona de Aragón aunque el rey de Mallorca estaba obligado a asistir a las Cortes de Cataluña y a prestar homenaje al rey de Aragón como conde de Barcelona. Sancho de MaIlorca realiza la aportación a cambio de que Jaime II le liberara vitaliciamente de asistir a dichas Cortes, por la supeditación que significaba.

De las 53 galeras que zarparon de Port Fangos, aparte de las veinte mallorquinas, dieciocho eran barcelonesas (33'47 por 100), diez valencianas (18'66 por 100), tres tarraconenses (5'66 por 100) y dos tortosinas (3'77 por 100). Además del gasto comportado por el armamento de las galeras, para financiar la empresa Cataluña concedió un subsidio de 1.193.000 sueldos barceloneses, el reino de Aragón 727.000 sueldos jaqueses y el reino de Valencia 696.000 sueldos valencianos. Por su parte, el reino de Mallorca concedió a Jaime II de Aragón un préstamo a fondo perdido de 500.000 sueldos barceloneses; a fondo perdido porque Mallorca tuvo que condonarlo.

Como la importante ayuda financiera aportada por los reinos como subsidio no bastó para financiar la empresa la Corona tuvo que empeñar -informa Zurita- parte de su patrimonio. Alude a la renta de la baronía de Entenza y del honor de Valderrobles y de Julisbol al arzobispo de Tarragona, además del monedaje de Zaragoza y de otras diversas rentas que cobraba la Tesorería Real en Cataluña, Valencia y Aragón.

En la campaña de 1323-1324 fallecieron, como relaciona nominalmente Pedro el Ceremonioso en su Crónica, el 69'23 por 100 de los caballeros aragoneses participantes, el 66'66 por 100 de los caballeros valencianos y el 50 '00 por 100 de los caballeros catalanes que participaron. Un tributo de sangre de todos los territorios de la expansión marítima de toda la Corona de Aragón y no sólo de Cataluña (47).

50. En la guerra contra Castilla, en la campaña de 1359 a tenor de la información del canciller López de Ayala la armada preparada por la Corona de Aragón para rechazar la flota castellana la integraban 40 galeras (Las galeras del rey de Aragón -escribe Ayala- eran quarenta, ni más ni menos), de las cuales veinte barcelonesas (50 por 100), diez valencianas (25 por 100), 5 mallorquinas (12'50 por 100), 2 tortosinas (5 por 100) y las tres restantes de Tarragona, Rosas y Colliure (7'50 por 100). 
La movilización naval sugiere que la Corona de Castilla, que con sus aliados el reino de Portugal y el de Granada armó 41 galeras para la campaña de 1319, estaba capacitada para armar una flota equivalente o mayor que la flota de la Corona de Aragón, y que a la superioridad de sus efectivos terrestres podía sumar llegada la ocasión importantes efectivos navales para adentrarse en aguas mediterráneas.

El endeudamiento del Real Patrimonio se produjo a pesar de la importancia de los servicios pecuniarios aportados por los reinos de la Corona. Por ejemplo, en 1376 las Cortes de Monzón como ayuda a la financiación de la guerra voluntaria e injusta que'l duc de Anjou segons que's diu vol moure, acordaron otorgar a Pedro el Ceremonioso un subsidio de 6.680 .000 sueldos barceloneses de los cuales el Principado de Cataluña y las islas de Menorca y de Ibiza devengarían 3.172.000 sueldos (47'48 por $100)$, el reino de Valencia 1.576 .000 sueldos (23'59 por 100$)$, el reino de Aragón 1.560.000 sueldos (23'35 por 100) y el reino de Mallorca, dado que las islas de Menorca y de Ibiza ofertaron su subsidio conjuntamente con el principado de Cataluña cuando lo más habitual era que lo devengaran con el reino de Mallorca, del que eran parte, tenía que satisfacer 390.000 sueldos (5'84 por 100).

Los subsidios que los reinos satisfacieron a la Corona con motivo de las empresas relacionadas con la expansión marítima, arruinaron sus finanzas y respaldan la afirmación de don Ramon d'Abadal: "La Corona de Aragón inicia en triunfo el siglo XIV y lo clausura con manifiestos signos decadentes ... Tal decadencia -se produce- determinantemente en el reinado de Pedro el Ceremonioso que ocupa más de la mitad de su tiempo: cincuenta y un años de 1336 a 1387 (48).

\section{Sobre el costo financiero de la expansión: el ejemplo de Mallorca}

51. ¿Cuál fue el costo de la política expansiva de Pedro el Ceremonioso que d'Abadal califica como de vanidad histórica? El estado de la investigación que sólo ha aportado escasa información fragmentaria no permite calcularlo. No obstante, las cuantificaciones sobre el costo de dicha política en Mallorca, aunque no son extrapolables pueden ser por lo menos sugeridas.

Datos sobre la aportación financiera de Mallorca a las empresas de Pedro el Ceremonioso entre 1349 y 1385 totalizan 25.764 .060 sueldos moneda del reino de Mallorca repartidos en los siguientes conceptos: 
Defensa de Mallorca (3)

445.000

1 '73

Guerra de Cerdeña (4)

7.150 .000

$277^{\prime} 75$

Guerra de Castilla (5)

16.539 .000

$64 ' 19$

Guerra del duque de Anjou (6)

669.000

2'60

Otros conceptos (7) 960.000

3'73

TOTALES

25.764 .060

100.00

(1) Las aportaciones se refieren a 25 años (1349-1356 y 1360-1385). No se contabilizan gastos de 1344 a 1348 ni de 1357 a 1359 . Tampoco se cuantifica el valor de 23 naves y "muchas galeras" perdidas el año 1364 en la guerra con Castilla según menciona Juan Binimelis en su Historia de Mallorca elaborada en 1597.

(2) En sueldos moneda de Mallorca.

(3) Sólo referidos a gastos contabilizados en 1349 y 1376.

(4) Años 1349 a 1356, 1366, 1368, 1369, 1371, 1379 y 1380.

(5) Años 1360 a 1367.

(6) Años 1356 (subsidio al matrimonio del infante Juan y guerra de Cerdeña), 1370 (donativo), 1371 (subsidio al infante Juan), 1374 (donativo) y 1382 (donativo).

Fuente: Juan Francisco López Bonet, Comunidad y Corona. El precio de servir. Las cargas sobre el consumo en el siglo XIV en Mallorca, Palma de Mallorca, Grup d'Estudis d'Història Econòmica, 1986, pp. 125-126.

52. La cuantificación afecta a 25 años pero, en la hipótesis de que los 25.764.000 sueldos significaran la totalidad de los donativos y subsidios devengados entre 1349 y 1385 , en 36 años, representan una media anual de 715.666 sueldos.

¿Qué significan 715.666 sueldos anuales? A tenor de datos referidos a 1372 los ingresos efectivos -no los ingresos teóricos- procedentes de los impuestos ordinarios ascendían a unos 660.000 sueldos anuales y el gasto público de la Administración comunitaria de Mallorca a unos 655.000 sueldos anuales (61.160 sueldos importe de la nómina de salarios que representan en 9'34 por 100 del gasto; 593.000 sueldos importe de los pagos de intereses de la Deuda Pública en concepto de violarios, censos en dinero y censos pagaderos en trigo que absorben el 90 '66 por 100 del gasto público), con un superavit testimonial de unos 4.880 sueldos anuales (0'74 por 100 de lo ingresado por impuestos).

La aportación media al Erario Real de 715.666 sueldos significa que la Administración de Mallorca, considerado el superávit testimonial de 4.880 sueldos, tenía que cubrir la diferencia resultante -710.786 sueldos- mediante la recaudación de tallas (contribución directa proporcional que gravaba el patrimonio neto de los contribuyentes) o emitiendo más Deuda Pública, el pago de cuyos intereses en 1372 absorbía nada menos que el 
90'66 por 100 del importe total recaudado un año por otro en concepto de impuestos ordinarios.

La apelación sistemática a emisiones de Deuda Pública para satisfacer subsidios a la Corona hipotecó el futuro, descargando para salir de apuros la amortización de la Deuda en las generaciones venideras, a las que se trasmite un patrimonio de deudas. Ello comportó la quiebra de la Administración Pública de Mallorca y la consignación al amparo del denominado Contrato Santo de 1405 de las imposiciones -de todas las imposiciones ordinarias- al pago de los intereses y amortización de la Deuda, a cuyo efecto los acreedores censalistas elegían anualmente un clavario al que incumbía controlar la recaudación, pagar las pensiones de los censos $y$, en su caso, si obraba excedente, amortizar la deuda.

El Contrato Santo, de acuerdo con lo establecido, debía mantenerse vigente hasta la amortización total de la Deuda. El objetivo de amortizar la Deuda no se alcanzó y la nombrada Junta Universal de la Consignación, encargada del control de los ingresos y gastos de la Administración, estuvo en ejercicio hasta su extinción en 1835 (Real Orden de 8 de enero cumplimentada el 25 de enero), subrogándose en sus competencias el Gobierno Civil de Baleares (49).

53. Además de la aportación en numerario con las graves secuelas expresadas, la política de expansión mediterránea repercutió en el tráfico mercantil por el mayor riesgo resultante del estado de guerra que aunque no solía colapsar el tráfico lo condicionaba y por la requisa de naves que solía comportar.

La Corona se apresuraba a ordenar la requisa cautelar de embarcaciones en caso de alarma o prevención de guerra. Vista la present-manda Pedro el Ceremonioso el 22 de mayo de 1371 al gobernador de Mallorca Olfo de Prócida-, procehiscats que totes les naus e lenys posat que sien cuberts en VII palms, sien detenguts e emparats -requisados-, axí que no guosen ne pusquen navegar a alscunes parts sino tan solament per les mars de dites Illes e per les parts de Catalunya i del regne de Valencia.

El mandato se cumplió el 28 de junio y aquel día la requisa -por reunir las condiciones señaladas en el mandato (naves cubiertas en siete o más palmos)- afectó a Mallorca a 15 cocas 2 naos y 2 leños que en conjunto desplazaban 1.874 toneladas. Otra carta real (Valencia 4 de julio de 1371) para atenuar los perjuicios de la requisa-dispuesta con vistas a intervenir en Cerdeña-, dispuso que las embarcaciones requisadas que tuvieren que 
rendir viaje a Pisa o a Berbería (en el litoral comprendido entre Orán y Túnez) o a Peñíscola para cargar abastecimientos con destino a Pisa quedaban exentas de la requisa en tanto prestaran garantía de retornar a los puertos de origen en cuanto hubiesen cumplimentado el contrato de flete.

En esta ocasión la requisa fue revocada mediado diciembre de 1371. Senyor vos fats saber -se lo comunicó desde Barcelona a Olfo de Prócida- que lo senyor rey ... ha ordonat que tot lo navili qui era romàs a Mallorques sia licenciat de anarsen. En el entre tanto, parte de las embarcaciones permanecieron inmovilizadas de fines de junio a fines de diciembre de 1371 con el consiguiente trastorno.

Los mercaderes solían lamentarse de los efectos negativos que acarreaba la política expansionista al trabar o paralizar el comercio. Per raho de la guerra -escriben los mercaderes barceloneses en 1453-, lo exercici mercantivol a les dites parts de Llevant lliberament nos pot exercir e lo dit exercici sia molt necessari a la nostra nació como sia fonament, cap e principi de tot lo negoci (50).

\section{Sobre la gravitación de la fiscalidad}

54. La tesis de una política exterior "dirigida i financiada per mercaders" referida a la "reintegració mediterrània del Cerimoniós", magnifica la influencia y el poder de la burguesía mercantil. La política exterior la dirige y la impone la Corona, sobre todo en la época tan proclive a la autocracia de Pedro el Ceremonioso, y la financian muy a desgana, bajo presiones, todos los territorios de la Corona de Aragón (parágrafos 48 a 50) por conducto de las Cortes y de los Consejos municipales a los que apela la Corona para obviar la resistencia de las Cortes.

Los estamentos sociales, entre ellos el mercader, se allanaban a financiar normalmente la política expansiva, que comportaba gastos insoportables, a requerimiento imperativo de la Corona. En octubre de 1360 una circular de Bernat de Tous, gobernador de Mallorca, notificó a los bailes de las villas de la isla que por mandato suyo hacía cinco días que los honrats jurats -de Mallorques-e altres prohomens de la ciutat e de fora -de las villas-, que integraban el Consell General de Mallorca, estaban retenidos en la Casa de la Juradería sede del mentado Consell. ¿Por qué? Porque no se avenían a otorgar el subsidio que pedía el rey, y el gobernador tuvo que recurrir a la retención para obligarles a que concedieran -como lo hicieron- los 960.000 sueldos moneda de Barcelona pagaderos en 
dos años, según había solicitado el rey en carta datada en Zaragoza el 2 de mayo de dicho año.

La financiación de la política expansionista al tiempo que contribuye a descapitalizar el Patrimonio Real incidió con incidencia determinante en el endeudamiento de los municipios. "Les rendes de la Corona amb les continues guerres - relata Ferran Soldevila refiriéndose a la época de Pedro el Ceremonioso-, havien minvat, havia calgut alienar patrimoni reial; el monarca havia anat, com he dit, fins a apoderarse de les rendes eclesiàstiques ... la noblesa havia estat delmada en les guerres inacabables. Els jueus havien hagut de patir els primers avalots adversos ... Grans i incomportables exaccions pesaven demunt el país segons feien constar amb protesta les Corts Generals de 1384 ... Ja a les acaballes del regnat de Pere III la situació d'aquells països catalans era ben precària, però se sostenien encara".

La Deuda Pública de Barcelona que en 1360 importaba 3.380 .000 sueldos con intereses que absorbían el 42 por 100 del total del importe del presupuesto municipal de gastos, importaba 5.920 .000 sueldos, con un crecimiento del 75'15 por 100, en 1386. El florín de oro creado en 1346 se había devaluado un 25 por 100 en 1365.

Françesc Eiximenis en 1383 instaba -ante el fenómeno de la expansión de la Deuda Municipal-, para que se prohibiera "comprar censales o violarios a todos aquellos que pudiesen mercadear, pues por más que tal cosa pueda hacerse justamente -argumenta- la realidad es que con ello se obstaculiza el comercio que, sin comparación alguna, es más útil a la comunidad".

"La sensación de malestar -comenta don Ramon d'Abadal- producida por la crisis es evidente. La recesión había llegado con su secuela de baja de precios, disminución de provechos y actividades e inflación de una Deuda Pública invertida en gastos muertos, como los de una guerra perdida, o dedicados a suntuosidades improductivas" (51).

55. La interpretación historiográfica de que Valencia se libra de la crisis que afectó a Cataluña y a Aragón por una "mena de inhibició" y porque "de les guerres d'Italia es pot dir que València no en treu sinó els avantatges", es más voluntarista que cabal.

$\mathrm{Ni}$ en las empresas italianas de Alfonso el Magnánimo ni en la expansión marítima o en las guerras peninsulares anteriores hubo inhibición de 
Valencia. "Los préstamos de Alfonso $\mathrm{V}$-afirma Francisco Sevillano aludiendo a los que le otorgó la ciudad de Valencia- vienen a ser como índices de su política y los más numerosos fueron motivados por la expedición y conquista del reino de Nápoles". Tales préstamos librados entre agosto de 1426 y mayo de 1455 totalizaron 2.846 .021 sueldos moneda de Valencia.

Valencia, aunque no comprendía la política de expansión mediterránea -que levantaba clamores en contra en toda la Corona de Aragón-, de Alfonso el Magnánimo, a pesar de su desacuerdo la apoyó a desgana pero con eficacia. Cuando el monarca expuso a las Cortes de Valencia de 1419 su proyecto de campaña los tres estamentos -el eclesiástico, el militar y el de las municipalidades-, se pronunciaron en el sentido de que abandonara la idea de pasar a Cerdeña y a Sicilia pues nada bueno cabía esperar del viaje.

Los tres estamentos de las Cortes le pidieron al monarca que permaneciera en los territorios peninsulares de la Corona. No obstante, comprendiendo que el rey no renunciaría a su proyecto, las Cortes se apresuraron a otorgarle un subsidio de 440.000 sueldos como contribución a la proyectada campaña que entendían inconveniente e inoportuna.

Valencia continuó prestando apoyo a todas las campañas de Alfonso el Magnánimo tanto en dineros como en armamento de naves y aportación de víveres y material de guerra. No sorprende que el monarca reconociera los grans serveys que de aquella -de Valencia- havem rebut e la gran afecció e bon zel-como manifiesta el 12 de mayo de 1425-que a nostro honor sempre a demostrat (52).

\section{Incidencia de la expansión en el desarrollo económico}

56. La expansión marítima mediterránea, al margen del prestigio dimanante del dominio político, incidió positivamente -contribuyendo con ello a compensar algún tanto su elevado costo- en la promoción económica de todos los territorios que la integraban y en especial de los marítimos. La incidencia se nota sobre todo en las siguientes áreas:

a) Incidencia en la contención del corsarismo

La cosa pública de vostres regnes e terres e en especial la ciutat de Barchinona, de Mallorques e de València e les altres ciutats e viles mariti- 
mes de aquelles, no pot ne deuen suportar los grans dampnatges -escriben los jurados de Valencia al rey el 7 de octubre de 1399-que reben cascun dia per mans de cossaris, pirates e altres persones de perverse condició qui ... irruexen contra vostres sotsmeses, desroban e levan a aquells lurs mercaderies, navilis e bens

Los jurados de Valencia sintetizan en dicha carta los perjuicios que el corsarismo reportaba: la mercaderia, en la qual gran part del bé de la cosa pública és conservada, cesa de tot, per tal com aquells que la costumen fer, per fogir de tals roberies, la desamparen; les terres s'empobrexen, no transfegán-se los havers que en aquelles se colen; los drets reyals e altres se perden, no haven que aquells pach; les universitats s'encarreguen no havent rebudes per pagar lurs necessaris despeses; e finalment, la cosa pública, stenuada per tants detrimens va en defecció.

\section{b) Acción dinamizadora en los sectores primario y secundario}

La preparación de las flotas generaba la natural demanda de aprovisionamiento: vino, bizcocho y galletas, queso y carnes saladas, salazones de pescado (anchoas, arenques, bacalao, toñinas), legumbres y frutas secas (higos, pasas, castañas), tejidos, en especial draps burells, cueros y pieles, medicamentos (triaca, cedróleos, estoraque, espliego, timiana, mirra).

Se reactivaba la actividad de los astilleros y de las manufacturas relacionadas con la fabricación de naves y de pertrechos: pavesos o escudos de diversos tamaños y formas, cervelleres o casquetes y celadas; lanzas longues, manesques y ab rampins, espadas, puñales, dagas y cuchillos; ballestas de torno y de martinet; pasadores con punta de hierro; bombardas y proyectiles o pedres de bombarda; buçons o arietes; pólvora, resina, pez, estopa; fustany o aparejos de madera para diversos usos; rems o remos, abres o mástiles (abres mestres, abres de mitjana, abres de trinquet): ferrera o herramientas muy diversas (barrines, destrales, claveres o barras de hierro, martillos, hachas); áncoras de diversos tamaños y rampagolls o ganchos de hierro; jarcias de cáñamo, gúmenas o cabos sueltos, rets o cuerdas gruesas, palomeras o cuerdas delgadas y resistentes, y otros pertrechos.

c) Promoción de mercados protegidos

Mercados en Cerdeña y, sobre todo, en el litoral norteafricano, en Sicilia y en Nápoles. Mercados proveedores de lanas, pieles, cueros y en particular de lo que solía necesitarse más: trigos. 
Mercados donde vender al amparo de privilegios que otorgan los monarcas los excedentes estables exportables en especial de pañería de confección artesanal (cordellates, burells, blanquets, brunetes, vervins, palmelles, vintés, vintiquetrens) fabricados en Cataluña, Valencia, Aragón y Mallorca que no tenían salida en otros mercados porque no eran competitivos con la pañería flamenca, inglesa, francesa o italiana.

Henri Bresc ha precisado como tras el Compromiso de Caspe y la instauración de la nueva dinastía Trastámara se potencia la implantación de la pañería de países de la Corona de Aragón en Sicilia sobre todo entre los años 1420 y 1459, por el apoyo que le presta Alfonso el Magnánimo (53).

\section{CONCLUSIÓN}

La expansión benefició a los territorios marítimos de la Corona, sobre todo a Cataluña y también a los reinos de Valencia y de Mallorca. En cuanto al reino de Aragón, reino interior con predominio de la renta agraria, participó más en las cargas, en el coste de la expansión, que en los beneficios de la expansión.

Entre las dos versiones historiográficas que obran sobre la expansión (la de las Crónicas elaboradas por los que participaron en la expansión que la interpretan como realización conjunta de todos los territorios de la Corona de Aragón, y la de cierta historiografía contemporánea actual que interpreta la expansión como fenómeno privativo catalán), es más fiable la coetánea, no sólo como más próxima a los hechos sino porque la expansión se realizó con sangre y dinero de todos los territorios de la Corona, y a todos los territorios de la Corona corresponde atribuirla, pues todos la sirvieron con sacrificio y abnegación.

Lo que cierta historiografía conceptúa como "imperio catalán" o "imperialismo catalán", referido a la expansión, ni existió ni podía existir no sólo por ser contradictorio con la doctrina jurídica imperante sino porque no obraban recursos militares ni económicos para establecer un imperio. $Y$ el criterio de que la expansión se desnaturaliza a partir de 1412 al asentarse la Dinastía Trastámara en la Corona de Aragón es una entelequia voluntarista. Cabalmente son los Trastámara los que culminan la expansión, sin que ello comporte su presunta castellanización, pese a la participación de recursos financieros y humanos castellanos en la época de Fernando el Católico. 


\section{NOTAS}

(1) LALINDE ABADÍA, J. (1229-1479), Zaragoza, CSIC, Institución Fernando el Católico, 1979.- El estudio presenta una síntesis global en los aspectos esenciales del tema articulados en cinco capítulos: Los Hechos (el desarrollo politico), Las Causas (las motivaciones y la financiación), Las Derivaciones (secuelas económicas, demográficas, sociales, financieras y monetarias), y Los Símbolos (desarrollo cultural: arte, historiografía, literatura, lingüística, mentalidades). Comentarios bibliográficos en pp. 99-102, 187-197, 251-258, 281-285 y amplio repertorio bibliográfico en pp. 287-336.

La obra de J. LEE SHNEIDMAN, The Rise of the Aragonese- Catalan Empire, 1200-1350, New York, Universitiy Press, 1970, traducida al catalán por Josep Vallverdú (capítulos I-VIII) y Francesc Gironella (capítulos IX-XV) con el título de L'Imperi Catalano-Aragonès 1200-1350, Barcelona, Edicions 62, 1975 , en dos vols. (I, Política Interior; II, Política Exterior), aporta consideraciones singulares y a veces poco informadas y escasamente rigurosas, si bien inserta en vol. II, pp. 275-350 un muestrario bibliográfico importante.

Merecen especial consideración los valiosos estudios de:

- HEYD, G. Storia del commercio del Levante nel Medio Evo, Torino, Biblioteca dell'Economista, 1913.

- SALAVERT, V. Cerdeña y la expansión mediterránea de la Corona de Aragón, 1297-1314, Madrid, CSIC, Escuela de Estudios Medievales, 1956, dos vols.

- HEERS, J. Génes au XV siecle. Activitè économique et problèmes sociaux, Paris, Ecole Practique des Hautes Etudes, Sixieme Section, SEVPEN, 1961.

- CARRERE, C. Barcelone centre économique a l'èpoque des difficultès, 1382-1462, Paris, Mouton, 1967.

- DUFOURCQ, Ch. E. L'Espagne Catalane et le Magrib au XIII et XIV siècle. Versión en catalán bajo el título L'Expansió catalana a la Mediterrània occidental. Segles XIII-XIV, Barcelona, Editorial Vicens Vives, 1960.

- TREPPO, M. del. I mercanti catalani e l'expansione della Corona d'Aragona nel secolo XV, Napoli, Arte Tipográfica, 1972.

- GIUNTA, F. Aragonesi e catalani nel Mediterràneo. Vol. I, Dal regno al viceregno in Sicilia; vol. II, La presenza catalana nel Levante dalle origine a Giacomo II, Palermo, U. Manfredi, 1972. 
En La Península Ibérica y el Mediterráneo centro occidental. Siglos XIII$X V$. Actas del primer Congreso Internacional de Historia Mediterránea (Palma de Mallorca, 17-22 de octubre de 1973), Barcelona-Roma, CSIC, 1980, se insertan aportaciones de interés entre las cuales importa considerar las siguientes:

a) Sobre la reconquista de las vías marítimas

- SANTAMARÍA, A. La reconquista de las vías marítimas, amplia síntesis global sobre el desarrollo de la coyuntura mediterránea del siglo XI al siglo XV, que continúa un nutrido apéndice de bibliografía selectiva (pp. 41-133, apéndice bibliográfico pp. 116-133).

- HILLGARTH, J.N. El problema del Imperio Catalano-Aragonés (1229-1337). Análisis crítico de la problemática de la expansión marítima centrado en Las limitaciones permanentes de la politica real, Limitaciones internas y limitaciones externas, Las causas generales de la expansión y la teoría de un imperio catalán (pp. 144-159). Se ha publicado una versión actualizada en catalán de dicha importante aportación bajo el título El problema d'un Imperi Mediterrani Català, Palma de Mallorca, Editorial Moll, 1984.

b) Sobre cristianos y musulmanes en el Mediterráneo occidental

- PISTORINO, G. Genova e l'Islam nel Mediterraneo occidentale. Secoli XIIXIII, pp. 190-206.

- DUFOURCQ, Ch. E. Chretiens et musulmans durant les derniers siècles du Moyen Age, pp. 208-209.

- TRENCHS ODENA, J. "De Alexandrinis". El comercio prohibido con los musulmanes y el papado de Aviñón durante la primera mitad del siglo XIV, pp. 238-320.

c) Colonias extranjeras en la Península lbérica

- BATLLE, C. Els françesos a la Corona d'Aragó, pp. 360-392.

- FERRER, M. ${ }^{a}$ T. Els italians a terres catalanes. Segles XII-XV, pp. 393-468.

- COSTA, M. ${ }^{\mathrm{a}}$ M. La Pau de 1428 i els mercaders genovesos de la Corona d'Aragó, pp. 554-584.

- ARIENZO, L. d'. Una nota sui consolati catalani in Sardeña nel secolo XIV, pp. 593-610.

d) Navegación y corso

- RUIZ DOMĖNEC, J.E. Ruta de las especias/Ruta de las Islas. Apuntes para una nueva periodización, pp. 689-697.

- MOLLAT, M. Essai d'Orientation pour l'etude de la guerre de course et la piraterie. XIIIe-XVe siècles, pp. 743-749.

- BRESC, H. Course et piraterie en Sicilie, 1250-1450, pp. 751-757.

- GUIRAL, J. Course et piraterie a Valence de 1410 a 1430, pp. 759-767.

(2) No sólo obra carga subjetiva en la historiografía española. "En la historiografía italiana del siglo XIX se observan bastantes apasionamientos antiespañoles -puntualiza Lalinde- que van eliminándose a medida que aumentan las relaciones científicas para llegar en la actualidad a una conducta pro catalano-aragonesa y pro-española, en general. Esta competitividad ... presenta más excepciones en la historiografía francesa parte de la cual es procatalana a fuer de anti-española o, al menos, anti-castellana. Los apasionamientos castellanos y catalanes en cuanto a una figura como Fernando I de 
Aragón han sido observados por un profesor italiano como Alberto Boscolo. Estos apasionamientos, curisamente, no dejan de estar presentes en los historiadores pertenecientes a otras nacionalidades, incluso en la literatura anglosajona, receptiva a los estímulos políticos de su presente y a los emocionales". LALINDE, J. La Corona de Aragón en el Mediterréno, pp. 51-52.

(3) SHNEIDMAN aclara su pensamiento y especifica: "El interes essencial d'aquesta obra es polític: examinar els problemes que s'alcen davant una nació en un període de transició, un període durant el cual -Catalunya- surt d'una relativa obscuritat a la llum brillant de comprovar que és una gran potència". L'Imperi catalano-aragonès, II, 263, 265-266, 268, 270-271.

SHNEIDMAN, por lo que se deduce no distingue entre la Unión aragonesa, movimiento de ricohombres, y la Unión valenciana liderada por ciudadanos que reaccionan ante "los caracteres autoritarios que estaba tomando el gobierno de la Monarquía", para "obtener de la Monarquía las garantías -llamémoslas constitucionales- que impidieran la repetición de las reiteradas violaciones por la corte de las leyes y privilegios del reino". RODRIGO LIZONDO, M. "La Unión valenciana y sus protagonistas", Ligarzas, 7, Valencia, 1975, p. 135.

Rodrigo Lizondo rechaza las interpretaciones de Reglà al reputar la Unión como "ofensiva de elementos feudalizantes", y de Sanchís Guarner al considerarla "aristocratitzant i proaragonesa" (pp. 145-146). Es problemático que Shneidman conozca el relato de la Crónica de Pedro el Ceremonioso, que desautoriza el apelativo de "ultres" que aplica a los unionistas valencianos y aragoneses y la interpretación como "justícia reial molt suau" la dura y cruel represión realizada en Valencia por Pedro el Ceremonioso. Crònica de Pere el Cerimoniós, Les Quatre Cròniques, Barcelona, Editorial Selecta, 1974, cap. IV, pp. 1109-1110.

(4) La desnaturalización de la expansión tras el Compromiso de Caspe es interpretación amparada en especial por Ferran Soldevila (Història Nacional de Catalunya, Editorial Alpha, Barcelona, 1963, pp. 618-619, 656, 661-662, 681683), por Joan Reglà (Introducció a la Història de la Corona d'Aragó, Palma de Mallorca, Editorial Moll, 1963, pp. 50,60,64) y por Ives Renouard ('Les principaux aspects économiques et sociaux de l'histoire des Pays de la Courenne d'Aragon au XIle, XIIle et XIVe siècles", VII C.H.C.A, Barcelona, 1962, p. 264).

Para el profesor Lalinde la expansión comenzó en 1229 con la reconquista de Mallorca y culmina, que no finaliza, con "la prisión y muerte del conde Jaime Picinino en 1465" -que- "marca la total sumisión del reino -de Nápolesal poder de Fernando I hijo natural de Alfonso el Magnánimo (La Corona de Aragón en el Mediterráneo, p. 51).

(5) SOLDEVILA, F. Història de Catalunya, p. 278.- SALAVERT, V. Cerdeña en la expansión mediterránea, I, pp. 37, 40,56.- MANCA, C. "Colonie iberiche in Italia nel secoli XIV e XV", La Península Ibérica y el Mediterráneo centro-occidental, p. 505.

(6) SANTAMARÍA, A. Reconquista de las vías marítimas, pp. 49-55.

(7) LE GOFF, J. Mercaderes y banqueros en la Edad Media, Buenos Aires, Editorial Universitaria, 1976, pp. 12-13.- LE GOFF, J. La Baja Edad Media, Madrid, 
Editorial Siglo XXI, 1974, pp. 29-47.- NICOLAU D'OLWER, Ll."'Entre les dues conquestes: 1115-1229", La Nostra Terra, Mallorca, any II, 1929, p. 522.DESCLOT, Crònica, Les Quatre Cròniques, cap. 14, p. 422.- Gonzalo de Reparaz alude al texto de Benjamín de Tudela sobre la actividad del puerto barcelonés de 1160 ("El comerç i la marina de Catalunya abans de la conquesta de Mallorca", La Nostra Terra, any II, p. 457). - SANTAMARÍA, A. "Determinantes de la conquista de Baleares", Mayurqa, 8, 1972, pp. 79-88.

(8) MARAVALL, J.A. El Concepto de España en la Edad Media, tercera edición, Madrid, Centro de Estudios Constitucionales, 181. "La reconquista como restauración de un dominio legítimo", pp. 254-261; "España como objetivo de una empresa histórica", pp. 287-295.- VALDEÓN BARUQUE, J. "Las particiones medievales en los Tratados de los reinos Hispánicos", I Coloquio luso-español de Historia de Ultramar, Valladolid, 1973.- CHABÁS, R. "División de la conquista de España mora entre Aragón y Castilla", / CHCA, Barcelona, 1909, publica texto del Tratado de Cazola en pp. 139-141.- Pactos sobre la campaña Baleares de Barcelona 23 de diciembre de 1228 y Tarragona 28 de agosto de 1229 publicados en FONTES RERUM BALEARIUM, Palma de Mallorca, Fundación Bartolomé March, 1977, pp. 18-19 y 22-23.- SANTAMARÍA, A. "La expansión político-militar de la Corona de Aragón bajo la dirección de Jaime I: Baleares", Ponencia X CHCA, Zaragoza, 1979, pp. 120-121.

DESCLOT, Crònica, Les Quatre Cròniques, cap. 13 p. 420, cap. 15 p. 422 , cap. 19 p. 423 , cap. 30 p. 425 , cap. 34 p. 428 , cap. 40 p. 438 .- GIUNTA considera que aunque no se pueden despreciar los contenidos económicos de la conquista de Baleares, la operación se inserta en el movimiento de la reconquista (Aragonesi e Catalani, II, pp. 23-24).- HILLGARTH interpreta que "les conquestes de Balears $i$ de València eren croades religioses $i$ ensemps guerres de reconquesta" (El problema d'un Imperi Mediterràni, p. 43).- RENOUARD, interpreta que "la conquete du royaume de Valence marque-t-elle le terme de la reconquista aragonaise" (Aspects économiques et sociaux, p. 239).

(9) Regesta de la Bula de Perugia de 12 de febrero de 1229 y del Breve de 13 de febrero de 1229 publicadas en FONTES RERUM BALERIUM, I, pp. 21-22. Texto de los Breves de Perugia de 29 de noviembre de 1229 y de Letrán de 23 de diciembre de 1229 publicado en FONTES RERUM BALEARIUM, I, pp. 26, 51-52.

(10) Vide bibliografía de la nota anterior.- SANTAMARÍA, A. Determinantes de la conquista de Baleares, pp. 106-112.

(11) SOLDEVILA, F. Història de Catalunya, pp. 309, 313-314.- GIUNTA, F. Aragonesi e catalani, II, pp. 42-55.- CARRERAS CANDI, F. "La creuada a Terra Santa, 1269-1270", I CHCA, Barcelona, 1909, pp. 196-138.- Crònica de Jaume I, Les Quatre Cròniques, parágrafo 385 p. 182.- ENGELS, O. "El rey Jaime I y la política internacional del siglo XIIl" $X$ CHCA, Zaragoza, 1979, pp. 215-240.

(12) SANTAMARÍA, A. "Creación del reino de Mallorca: las disposiciones testamentarias de Jaime I", Mayurca, 19, 1978-1980, pp. 125-144.- GIUNTA, F. Aragonesi e catalani, II, p. 57-68.- BRANCATO, F. "Considerazioni sulle celebrazioni del Vespro de 1228”, IX CHCA, Palermo, 1983, II, pp. 223-240.- 
BRESC, H. "1282: Classes sociales et revolution nationale", XI CHCA, II, pp. 241-258.- GATTO, L. "La guerra del Vespro primo della ricostruzione di Michele Amari", XI CHCA, III, pp. 165-176.- MARTÍNEZ ORTIZ, J. "Los sucesos de Palermo y su preparación en un autor valenciano del siglo XVII", XI CHCA, IIl, pp. 305-320.

SANTAMARÍA, A. "Enfeudación de la Corona de Mallorca a la Corona de Aragón", XI CHCA, IV, 187-211.- SOLDEVILA juzga que "la partició feta per Jaume I era antinacional, insensata, ridícula, si es vol. Un colp feta, però, la millor solució hauria estat que les dues branques dinastiques -la de Barcelona i la de Mallorca- haguesin viscut en la més clara harmonia i en la més estreta aliança" (Història de Catalunya, p. 464).

HILLGARTH subraya que "encara que I'historiador oficial de Pere, Desclot, no ho admeti, no hi pot haver dupte que l'expedició -que Pedro de Aragón insinuaba como preparada contra sarracenos- anava de benantuvi ja adreçada contra Carles de Anjou i el seu reialme de Nàpols i Sicília" (El problema d'un Imperi mediterrani, p. 60).

(13) REGLÀ, J. Introducció a la Corona d'Aragó, pp. 41, 60.- ABADAL i de VINYALS, Ramon d'. "Pedro el Ceremonioso y los comienzos de la decadencia política de Cataluña", "Introducción" al vol. XIV de la Historia de España dirigida por Ramón Menéndez Pidal, Madrid, Espasa Calpe, 1958, pp. CLXXIIICLXXIV, CXCIX-CCI.- LECOY DE LA MARCHE, A. Les relations politiques de la France avec le royaume de Majorque, Paris, Ernest Leroux, 1892, I, pp. 151-311.

(14) SOLDEVILA considera que, pese a su hegemonía, no obraba una política asimilista catalanizadora ("Els catalans en conjunt no van donar mai proves de sentir profundament el deler d'aconseguir totes les prerrogatives inherents a la seva hegemonia de fet i d'imposer-se de mica en mica als altres països de la Corona") en contraste con la postura manifestada por Aragón frente a Valencia ("mentre veien els aragonesos esforçarse gelosament i tenaçment a conservar les preeminències, adhuc que normals, del titol de reialesa unit a llur territori ... València, tot i poblat en la seva major part de catalans, no sigui sinò una prolongació del reialme aragonés i els catalans mostren una mena d'indiferència") y el asimilismo que pudiera practicar Aragón de contar con más recursos ("Si els reis haguessin estat aragonesos en lloch de ésser catalans, i si Aragó no hagués estat com era un pais pobre i gents poblat ... potser s'hauria produit un esforç d'assimilació i de penetració aragonesa a Catalunya") (Història de Catalunya, pp. 457-458, 535, 537-538, 661-662, 671-672, 682-683, 692, 852-853).

TOMICH, P. Històries e conquestes dels reys de Aragó e de llurs antecessors los comtes de Barcelona, reimpresión facsímil de la de 1534, Valencia, Editorial Anúbar, 1970, pp. 8, 126-128.

(15) SANTAMARÍA, A. "Alfonso el Magnánimo y el levantamiento foráneo de Mallorca", Estudios sobre Alfonso el Magnánimo, Barcelona, Universidad, 1960, p. 136-137. VACCARI, P. "Maestri e discipoli spagnuoli nell'Universita de Pavia nell'eta de Ferdinando il Cattolico", V CHCA, Zaragoza, 1956, III, pp. 261265. BRESC, H. "La Draperie catalane au miroir sicilienne", Acta Medievalia, 4, 1983, pp. 108-127. 
(16) MARTÍNEZ FERRANDO, E. Història dels Catalans, Barcelona, Editorial Ariel, 1979, pp. 1136-1161.- REGLÀ, J. Introducció a la Corona d'Aragó, pp. 60.- VICENS VIVES, J. "La economía de la Corona de Aragón en la baja Edad Media", Historia Social y Económica de España y América, Barcelona, Editorial Teide, 1957, II, pp. 339-340.- RENOUARD, I. Aspects économiques et sociaux, p. 264.- DEL TREPPO, M. I mercanti catalani nel secolo XV, premessa p. XI-XIII, pp. 584-585.- GIUNTA, F. Aragonesi e catalani, I, pp. 360-372.

(17) $\mathrm{TOMICH}, \mathrm{P}$. Històries e conquestes dels reis de Aragó, pp. 140-141.SUÁREZ, L. "1500 Un giro radical en la política de los Reyes Católicos", La España Medieval, Madrid, Universidad Complutense, VI, 1986, p. 1265.

VICENS VIVES sugiere que la designación del infante Fernando como rey de Sicilia en 1468 pudo ser una argucia de Juan II que "reservándose la plenitud de su poder como monarca de la isla mediterránea ... se proponía dar un golpe de efecto con vistas a su política exterior" (Fernando // de Aragón, Zaragoza, Institución Fernando el Católico, 1962, pp. 199-202).

PIERI, P. "Gonsalvo di Cordova e le origine del moderno esercito spagnoIo", V CHCA, Zaragoza, 1956, III, pp. 212, 225.- PIERI, P. "Alfonso V d'Aragona e le armi italiane", IV CHCA, Palma de Mallorca, 1955, I, pp. 121-126.- VICENS VIVES, J. La economía de Aragón, p. 15.

Charles VERLINDEN ha puesto de relieve los esfuerzos de Fernando el Católico de 1484 para salvaguardar los intereses económicos de la Corona de Aragón en Nápoles ("Les influences italiennes dans l'economie et dans la coIonisation espagnoles de l'epoque de Ferdinand le Catholique", V CHCA, Zaragoza, III, pp. 269-283).

Ernesto PONTIERI ha señalado como Fernando el Católico tenía plena conciencia de la significación de Sicilia y de Nápoles para la Corona de Aragón ("Ferdinando il Catolico e i regni di Napoli e de Sicilia nella storiografia italiana dell'ultimo cinquantenio", V. CHCA, III, pp. 229-249).

Ricardo FILANGIERI ha publicado una relación de la entrada en Nápoles de Fernando el Católico en 1506 ("Arrivo di Ferdinando il Catolico a Napoli. Relazione dell'oratore Viovanni di Medina al cardenal d'Este", VCHCA, III, pp. 311-314).

(18) DOUSSINAGUE, J.M. ${ }^{\text {La }}$ Lolítica internacional de Fernando el Católico, Madrid, Espasa Calpe, 1944, pp. 129-138, 615.- TOMICH, P. Històries e conquestes dels reis de Aragó, p. 143.- TORRE, A. de la. "La política de los Reyes Católicos en Africa. Antecedentes y orientaciones", Cursos de Conferencias sobre la política de los Reyes Católicos, Madrid, Instituto de Estudios Africanos, II, pp. 151-171.- ROMEU DE ARMAS, A. "Directrices de la política internacional de Fernando el Católico", Cursos de Conferencias .... II, pp. 107-128.- TORRES FONTES, J. "La proyectada expedición africana de Fernando el Católico en 1511", Hispania, 19, 1959, pp. 49-51.- GIL GUASCH, A. "Fernando el Católico y los consulados catalanes de Africa", V CHCA, II, pp. 105-122.

La actual historiografía tiende con racionalidad a extender la problemática de la expansión de la Corona de Aragón por lo menos hasta el siglo XVI. Al efecto, el VIII Congreso de Historia de la Corona de Aragón (Valencia, 1967) ya abordó la temática del siglo XVI, y el tema del IX Congreso (Nápoles, 
1973) fue: La Corona de Aragón y el Mediterráneo. Aspectos y problemas comunes desde Alfonso el Magnánimo a Fernando el Católico (1476-1516.

(19) SOLDEVILA, F. Història de Catalunya, p. 278.

(20) SOLDEVILA, F. Història de Catalunya, p. 390.

(21) SOLDEVILA, F. Història de Catalunya, pp. 417, 424.

(22) "Pere el Cerimoniós mori, tan mateix (1387) abans que els ducats hagin cayguts en llur poder", puntualiza SOLDEVILA, por lo que dada la inhibición de Juan I el ducado catalán de Atenas dejó de existir circa 1390. (Història de Catalunya, pp. 424-425, 507-508).

(23) SOLDEVILA, F. Història de Catalunya, pp. 9, 395, 422. Cita 430.

(24) SOLDEVILA, F. Història de Catalunya, pp. 365, 435.

(25) REGLÀ, J. Introducció a la Corona d'Aragó, pp. 28, 31, 41.- SHNEIDMAN, J. L'Imperi catalano-aragonés, II, pp. 62-63, 73, 271.- BAUTIER, R.H. "Les grands problèmes politiques et économiques de la Mediterranée médiévale", Revue Historique, 239, 1965, pp. 22-23.

(26) "Catalans e aragonesos", par. 7 y 39; "crestians, sarraiins o moros", par. 59, $60,63,64,65,70,71,72,77,80,83,86,87,89$, entre otros; "algaravia", par. $74,87,118,189,312$; "nostre llati", par. 87, 312; "arabig", par. 367; "Nos enviarem dos sarraïns ab la resposta e la u d'aquells era llatinada", par. 411. Crònica de Jaume I, Les Quatre Cròniques.

(27) "Crestians e sarraïns", cap. 5 pp. 410.412, cap. 13 p. 421, cap. 15 p. 422, cap. 19 p. 423 , cap. 30 pp. $425-426$, cap. 34 p. 428 , cap. 25 p. 429 , cap. 36 pp. 429-430, cap. 47 p. 439 , cap. 85 p. 473 , cap. 88 p. 475 ; "almogàvers i golfins", cap. 79 pp. 467-468; "batalla naval de Rosas-Palafrugell", cap 156 pp. 574575; "persecución del ejército francés en retirada" cap. 167 p. 582 . Crònica de Bernat Desclot, Les Quatre Cròniques.

(28) Introducción de NICOLAU D'OLWER, pp. 11-12. Crònica pp. 13, 38, 67-68, 96-97, 103-104 (MUNTANER, Expedició dels catalans a Orient. Text, introducció, notes i glossari per Lluis NICOLAU D'OLWER, Barcelona, Els Nostres Clàssics, 1926). Referencia a Ramon Llull, HILLGARTH, J.N. El problema de l'Imperi mediterrani, p. 31.

(29) HILLGARTH, J.N. Imperio catalano-aragonés, p. 156.- Crònica de Pere el Cerimoniós, Les Quatre Cròniques, cap. III, par. 195 p. 1087.

(30) "Il catalanismo che se affermò tra la fine del secolo XIX e i primi decceni di questo, è un fenomeno assai complesso in cui, su una base psicologica -il sentimento colletivo dell grupo- agì il rinnovamento linguistico e letterario operate dalla culture del Renaiximent, ma soprattutto la coscienza e la volontà politica di una borghesia industriale in forte ascensa. Questa, respinta e delusa nelle sue aspirazioni de diventare la classe dirigente della Spagna moderna, fini per repiegare sull'esigenza di un'organizzazione regionale autonoma, all'unitarismo castigliano oppone un nazionalismo catalano". DEL TREPPO, M. I mercanti catalani, p. 582.

(31) VICENS VIVES, J. Economía en la baja Edad Media, pp. 7, 9, 11.- DEL TREPPO, M. I mercanti catalani, pp. 2, 4, 5-6.- GIUNTA, F. Aragonesi e catalani, II, pp. 9-11.- RUIZ DOMĖNEC, J.E. "Ruta de las especias/ruta de las Islas", La Península Ibérica y el Mediterráneo, pp. 696-697.- HILLGARTH, J.N. El problema d'un Imperi, pp. 106-107. 
(32) SANTAMARÍA, A. Enfeudación de la Corona de Aragón, pp. 198-199.- Los testamentos de Pedro III ( 3 de junio de 1282) y de Alfonso III (10 de marzo de 1287) publicados por Alfonso GARCÍA GALLO, "El Derecho de Sucesión al trono en la Corona de Aragón", Anuario de Historia del Derecho Español, 1966, pp. 149-152.

(33) SALAVERT, V. La Corona de Aragón en el Mediterráneo, p. 45.- SALAVERT, V. Cerdeña y la expansión mediterránea, I, pp. 177-178.- DEL TREPPO, M. I mercanti catalani, 3.- La carta de Jaime II datada en 1311 y dirigida a Clemente $\mathrm{V}$ publicada por SALAVERT, V. Cerdeña y la expansión mediterránea, II, $\mathrm{p}$. 197.

(34) "Come se fosse soltanto -la expansión- suggerita o condicionata da avvenimenti contingenti". GIUNTA, F. Aragonesi e catalani, II, pp. 18-19.

"A menudo se intenta explicar la política catalana haciéndola mucho más consistente de lo que fue ... Sólo unas determinadas políticas de carácter general pueden percibirse claramente. Los historiadores están prontos a aferrarse a las pocas ocasiones en que se formulan medidas de carácter general en fuentes coetáneas y acostumbra a usar estos informes para explicar la política de un íntegro reinado o de una larga serie de reinados sin considerar el contexto en el cual tal declaración se hizo". HILLGARTH, J.N. Imperio catalano aragonés, p. 146.

Este -alude al proyecto de expansión- no ha constituido un plan programado, sino el resultado al que se ha ido llegando progresivamente y a través de diversas circunstacias felices". LALINDE, J. Mediterráneo Medieval, 9, 87.

(35) RENOUARD, I. Aspects économiques et sociaux, p. 243.- ESTEPA, C. "Algunes consideracions sobre la crisi económica a la Baixa Edat Mitjana: Barcelona i les ciutats comercials mediterrànies", Acta Medievalia, II, 1981.- ABADAL, R. d'. "Introducción...", pp. XVI, LXXVIII-LXXIX, CXXXVIII-CXXXIX, CCXXII.

(36) SANTAMARÍA, A. "La expansión político-militar de la Corona de Aragón bajo Jaime I: Baleares", $X$ CHCA, ponencias, Zaragoza, 1079, pp. 122-123.- SANTAMARÍA, A. "Comunidades occitanas en la conquista y repoblación de Mallorca", El regne de Mallorca i el sud de Francia, Palma de Mallorca, Institut d'Estudis Baleàrics, 1986, pp. 9-19.- SANTAMARÍA, A. Determinantes de la conquista de Baleares, pp. 79-81.

Las comunidades urbanas a las que se asignan caballerías-módulo en el Llibre del Repartiment de Mallorca, en la porción del realengo son las siguientes: Barcelona (877 1/2), Marsella (636), Tarragona (368), Lérida (198), Manresa (80 1/2), Villafranca (52 1/4), Argilés (48), Montblanch (41), Caldés (39), Gerona-Besalú (35 1/2), Tárrega (34), Cervera (31), Villamajor (28), Prades (22 1/2), Apiera (22), Narbona (18 1/2), Naves genovesas (28). Las cantidades entre paréntesis indican el número de caballerías-módulo recibidas.

La relación afecta a las comunidades que se citan en el Llibre del Repartiment, pero debieron participar otras no mencionadas. Por ejemplo, Montpeller que no figura en la relación y que sin embargo recibe un importante patrimonio urbano constituido por 100 casas que significan el 3'7 por 100 del total de casas (3.527) repartidas en la Ciudad de Mallorca, y el 4'69 por 100 de casas (2.132 casas) repartidas en el realengo. ARM, Códice 18, Llibre del Repartiment de Mallorca, f. $24 \mathrm{v}-25,30 \mathrm{v}$. 
A los 200 caballeros aportados por el rey en primera instancia deben añadirse, de ser cierto lo que nos indica la Crónica Real, 150 más que trae consigo Pedro Martel y 30 que aporta Pere Liçana, ambos en el período subsiguiente a la toma de la ciudad. CATEURA, $P$. "Sobre la aportación aragonesa a la conquista de Mallorca", X CHCA, Zaragoza, 1980, comunicaciones 1 y 2 , p. 27.

El coeficiente de $29^{\prime} 41$ corresponde a los 200 caballeros aragoneses que embarcan en Salou calculado sobre el total de 680 caballeros catalanes, bearneses, occitanos y aragoneses que se menciona en el pacto concluido en 28 de agosto de 1229 en Tarragona -que ratifica el convenido en Barcelona en 23 de diciembre de 1228-, o sea, sólo ocho días antes de que zarpara la expedición. Caballeros en el sentido de cavalls armats. SANTAMARÍA, A. La expansión político-militar: Baleares, pp. 122.

Los datos se refieren a efectivos que toman parte en la operación de reconquista, no a la participación en el asentamiento repoblador que es temática distinta.

(37) HILLGARTH, J.N. Imperio catalano-aragonés, pp. 153-154.- DEL TREPPO, M. I mercanti catalani, p. 149-153.- SALAVERT, V. "Los motivos económicos de la conquista de Cerdeña", VI CHCA, Cerdeña, 1960, p. 554.- SALAVERT, V. Cerdeña y la expansión mediterránea, pp. 160-187.

"Les ambicions de la Corona i dels mercaders de Barcelona eren virtualment inseparables ... Però de fet Barcelona no controlava pas la política de Jaume 11 ... Els drets dinàstics i els sentiments religiosos eren potser més importants per aquets hòmes -Jaume I, Pere II, Jaume II- que els factors econòmics". HILLGARTH, J.N. El problema d'un Imperi mediterrani, pp. 114115.

(38) TASIS, R. Pere el Cerimoniós i els seus fills, Barcelona, Editorial Vicens Vives, 1962, p. 93.- REGLÀ, J. "La Corona de Aragón", Historia de España, tomo XIV, Espasa Calpe, pp. 492-494, 508-511.- VICENS VIVES, J. Els Trastàmares, Barcelona, Editorial Teide, 1962, pp. 135-136.

SOLDEVILA, F. Història de Catalunya, pp. 648-687.- MARTÍNEZ FERRANDO, E. Història dels Catalans, Barcelona, Editorial Ariel, III, p. 1184.SHNEIDMAN, J. L'Imperi catalano-aragonès, II, pp. 43-72, 73-110, 111-156.

(39) Crònica de Jaume I, Les Quatre Cròniques, par. 547 p. 186.- Crònica de Ramon Muntaner, Les Quatre Cròniques, entre otras referencias cap. 29 p. 849, cap. 202 pp. 847-848, cap. 202 p. 849, cap. 214 p. 857, cap. 215 p. 857, cap. 219 p. 860, cap. 220 p. 861.- Crònica de Pere el Cerimoniós, Les Quatre Cròniques, cap. 5 par 1 p. 1111.- TOMICH, P. Històries e conquestes dels reis de Aragó, pp. 104 y 106.

(40) Crònica de Desclot, Les Quatre Cròniques, cap. 166 p. 577.

(41) DUFOURCQ, Ch. E. L'Expansió catalana, pp. 293-294, 515-518.

(42) Crònica de Ramon Muntaner, Les Quatre Cròniques, cap. 292 pp. 833-834.GIUNTA, F. Aragonesi e catalani, II, pp. 91-97.- SANTAMARÍA, A. "Mallorca en el siglo XIV", La Investigación de la Historia Hispánica en el siglo XIV. Actas del I Simposio de Historia Medieval, Madrid, CSIC, 1973, pp. 180-184.RIERA, A. El reino de Mallorca y el municipio de Barcelona. Las relaciones durante la segunda fase del reinado de Jaime /l de Mallorca, resumen de te- 
sis doctoral, Barcelona, Universidad, 1979.- RIERA, A. "La lezda balear de 1302. Un punto de fricción entre el reino de Mallorca y las ciudades mercantiles catalanas", Estudis i Documents dels Arxius de Protocols, IX, Barcelona, 1981, pp. 105-106.

(43) GIUNTA, F. Aragonesi e catalani, II, pp. 16-17.- HILLGARTH, J.N. Imperio catalano-aragonés, pp. 157-159.- HILLGARTH, J.N. El problema d'un Imperi mediterrani, pp. 16-23, 107-108.

(44) RENOUARD, I. Aspects économiques et sociaux, pp. 260-261.- DEL TREPPO, M. I mercanti catalani, p. 5.- SALAVERT, V. "La Corona de Aragón en el mundo mediterráneo en el siglo XIV", XIII CHCA, Valencia, 1973, pp. 56-57.HILLGARTH, J.N. El problema d'un Imperi mediterrani, p. 101.- VENTURA, J. "Catarisme a Catalunya", Boletín de la Real Academia de Buenas Letras de Barcelona, 28, 1959-1960, pp. 75-118.- VENTURA, J. "Catarisme als països catalans", VII CHCA, Barcelona, III, pp. 123-134.

(45) GIUNTA, F. Aragonesi e catalani, II, p. 16.- Crònica de Jaume I, Les Quatre Cròniques, par. 6 p. 5, par. 11 p. 7.- Crònica de Desclot, Les Quatre Cròniques, cap. 136 p. 527.- Crònica de Muntaner, Les Quatre Cròniques, cap. 29 p. 691.

(46) FALCÓN, I, "Repercusiones en las ciudades y villas aragonesas de la política mediterránea de Pedro III el Grande", XI CHCA, Palermo, 1984, III, pp. 101126.- El total de 1.094.000 sueldos se distribuyen de este modo: obispado de Tarragona 321.000 sueldos; de Barcelona 295.000 sueldos; de Gerona 196.000 sueldos; de Lérida 194.000 sueldos; de Tortosa 88.000 sueldos. HILLGARTH, J.N. El problema d'un Imperi mediterrani, p. 28.

Sobre la revuelta de Berenguer Oller, Crònica de Desclot, Les Quatre Cròniques, cap. 133, pp. 517-518.- BATLLE, C. La crisis comercial y económica de Barcelona a mediados del siglo XIV, Barcelona, CSIC, 1973, I, pp. 36-42. Sobre los privilegios otorgados al reino de Valencia, SANTAMARÍA, A. "La política municipal de Alfonso el Liberal en el reino de Mallorca", La Ciudad Hispánica durante los siglos XIII al XVI, Madrid, Editorial Universidad Complutense, 1985, 1295-1299.

Sobre el Privilegio General de Aragón, GONZÁLEZ ANTÓN, L. Las Uniones aragonesas y las Cortes del Reino (1283-1301), Zaragoza, CSIC, I, 81 y $176 ;$ II, 21 y 216.

Ferran SOLDEVILA denomina al Recognoverunt Proceres "Carta de les llibertats barcelonines" y considera que sus efectos fueron estimulantes de la prosperidad de Barcelona, "per la seva creixença i per al seu enriquiment" (Jaume li Pere el Gran, Barcelona, Editorial Vicens Vives, 1961, p. 148).

Impuesto a las aljamas en HILLGARTH, J.N. El problema d'un Imperi mediterrani, pp. 23-24.

(47) ARRIBAS PALAU, A. La conquista de Cerdeña por Jaime // de Aragón, Instituto de Estudios Mediterráneos, 1952, p. 149.- MATEU LLOPIS, F. "La política monetaria de Alfonso IV de Aragón (1327-1333) y su repercusión en Cerdeña", Anuario de Estudios Medievales, 7, 1971-1972, pp. 340-349.

SANTAMARÍA, A. "Tensión Corona de Aragón-Corona de Castilla. La sucesión de Sancho de Mallorca (1318-1336)", Estudios en Homenaje del profesor Salvador de Moxo, Madrid, Universidad Complutense, 1982, II, pp. 438-442. 
ZURITA, J. Anales, Lib. IV, cap. 43, vol. III, Zaragoza, Institución Fernando el Católico, p. 149.- Crònica de Pere el Cerimoniós, Les Quatre Cròniques, cap. I par. 13, p. 1010.

(48) ABADAL, R. d'. "Introducción...", pp. CLXXIII-CLXXV.- QUADRADO, J.M. a Privilegios y franquicias de Mallorca, Palma de Mallorca, Escuela Tipográfica Provincial, 1894, pp. 149-150.- ABADAL, R. d'. “Introducción...”, p. IX.

(49) SANTAMARÍA, A. "El reino de Mallorca en la primera mitad del siglo XV", IV CHCA, Palma de Mallorca, 1955, Ponencias, Edición anastática, Barcelona, 1976, pp. 58-65.

(50) SANTAMARÍA, "El gobierno de Olfo de Prócida. Una década de la Historia de Mallorca (1365-1374)", Hispania, 25, 1965, pp. 64-69. SOLDEVILA, F. Història de Catalunya, pp. 687, 693-694.

(51) REGLÀ, J. Introducció a la Corona d'Aragó, p. 45.- Archivo del Reino de Mallorca, LR, 21, 1359-1360, f. 114 y 189.- SANTAMARÍA, A. El reino de Mallorca en la primera mitad del siglo XV, p. 38.- SOLDEVILA, F. Història de Catalunya, pp. 491 y 506.- ABADAL, R. d'. "Introducción...", pp. XL-XLI.

(52) SOLDEVILA, F. Història de Catalunya, p. 694.- SEVILLANO, F. Préstamos de la ciudad de Valencia a los reyes Alfonso $V$ y Juan II (1426-1472), Valencia, Instituto Valenciano de Estudios Históricos, 1951, p. 91.- SANTAMARÍA, A. Aportación al estudio de la economía valenciana durante el siglo XV, Valencia, Instituto Valenciano de Estudios Históricos, 1966, pp. 57-59, 87-90. Datos para el estudio de la aportación de Valencia a la política de Alfonso el Magnánimo en pp. 183-214.

(53) RUBIO VELA, A. Epistolari de la Valencia Medieval, Valencia, Universidad, Biblioteca Sanchis Guarner, 1985, pp. 133-134.

"Le Compromis de Casp -comenta Henri BRESC- no signale aucun gran éche, aucune inversion de la tendance ni rupture a court terme; et l'on n'observe pas non plus de décadence des trafics ou de la presence catalanes dans les decennies successives, tandis que le rôle d'Alphonse semble bien que les avoir favorisés au maximum tant dant la domaine marchand que dans ceux de la haute administration et de la feodalité" ("La draperie catalane au miroir sicilienne", 1300-1460, Acta Medievalia, 4, 1983, pp. 108-127, cita p. 126). 